\title{
The stationary phase-specific sRNA fimR2 is a multifunctional regulator of bacterial motility, biofilm formation and virulence
}

Nicole Raad ${ }^{1,2}$, Disha Tandon ${ }^{2,3}$, Siegfried Hapfelmeier ${ }^{3}$, \& Norbert Polacek ${ }^{1,4, *}$

${ }^{1}$ Department of Chemistry, Biochemistry, and Pharmaceutical Sciences, University of Bern, Bern, Switzerland

${ }^{2}$ Graduate School for Cellular and Biomedical Sciences, Bern, Switzerland

${ }^{3}$ Institute for Infectious Diseases, University of Bern, Bern, Switzerland

${ }^{4}$ Lead Contact

*Norbert Polacek: norbert.polacek@unibe.ch

\section{Summary}

Bacterial pathogens employ a plethora of virulence factors for host invasion, and their use is tightly regulated to maximize infection efficiency and manage resources in a nutrient-limited environment. Here we show that during Escherichia coli stationary phase the small non-coding RNA fimR2 regulates fimbrial and flagellar biosynthesis at the post-transcriptional level, leading to biofilm formation as the dominant mode of survival under conditions of nutrient depletion. fimR2 interacts with the translational regulator CsrA, antagonizing its functions and firmly tightening control over motility and biofilm formation. Generated through RNase E cleavage, fimR2 regulates stationary phase biology independently of the chaperones $\mathrm{Hfq}$ and ProQ. The Salmonella enterica version of fimR2 induces effector protein secretion by the type III secretion system and stimulates infection, thus linking the sRNA to virulence. This work reveals the importance of bacterial sRNAs in modulating various aspects of bacterial physiology including stationary phase and virulence. 


\section{Keywords}

sRNA, ncRNA, biofilm formation, type 1 pilus, type III secretion system, virulence, motility, stationary phase, RNase E, CsrA

\section{Highlights}

- fimR2 expression causes biofilm formation and alters bacterial outer membrane architecture

- fimR2 modulates CsrA activity and sequesters it from its targets

- The Salmonella fimR2 variant is functional in E. coli

- $\quad$ fimR2 is generated through RNase E processing and enhances infectivity

\section{Introduction}

The ability of bacterial pathogens to infect and invade a host critically relies on the presence of adequate conditions promoting the survival of the pathogen within the said host, and the available arsenal of virulence factors allowing the execution of the various infectious steps. Once initial contact has been established and infection initiated, pathogens have to navigate their way through the various assaults of the host immune response, fighting back at times and defending their grounds at others, to reach regions with more resources. In this process, attacking bacterial pathogens express and employ a variety of virulence factors that either harm the host, such as toxins, or promote tissue invasion, such as adhesins (Wilson et al., 2002). For instance, several Gram-negative pathogens such as enterohaemorrhagic Escherichia coli $(E H E C)$, enteropathogenic E. coli (EPEC), enteroinvasive E. coli (EIEC), and Salmonella enterica serovar Typhimurium employ the type III secretion system (T3SS) to deliver a wide range of effector proteins directly into the cytoplasm of their target cells (Kaper et al., 2004, Galán, 2021) and these effectors cause cytotoxicity and manipulate the actin cytoskeleton to promote bacterial invasion. Uropathogenic E. coli (UPEC) use their type 1 pili (T1P) to adhere to and invade bladder epithelial cells (Martinez et al., 2000) while S. enterica uses the same pili to bind microfold cells within the intestinal lumen (Hase et al., 2009). 
Which virulence factors to use and when to employ them are two important aspects for microbial infections not only to ensure a successful attack, but also to minimize the loss of resources for the pathogen in an unpredictable and harsh environment (Sy and Tree, 2021). For these reasons, bacterial virulence factors are under tight regulation via multiple mechanisms acting in concordance and have been refined across long stretches of evolutionary history. CsrA is a translational regulator that governs the expression of T3SS effectors in both $S$. enterica and $E$. coli. For instance, CsrA downregulates hilD, the SPI-1 (Salmonella pathogenicity island 1) encoded regulator, and by doing so, inhibits the expression of multiple HilDdependent T3SS effectors (Martínez et al., 2011). In EPEC, CsrA induces flagellar motility and the expression of some T3SS effectors involved in Attaching/Effacing (A/E lesions) (Bhatt et al., 2009). Both Salmonella and $E$. coli regulate the expression of T1P through phase variation (Henderson et al., 1999), allowing some members of isogenic populations to display the pilus and others to retract it. However, the precise modes of regulations are far more intricate. In Salmonella, the expression of T1P is controlled by regulatory proteins FimZ, FimY, and FimW that affect expression from the single promoter of the fimAICDHF operon encoding T1P (Kolenda et al., 2019). In E. coli, the promoter of fimAICDFGH-encoding T1P lies within an invertible DNA region (Abraham et al., 1985) called fimS, and recombinases FimB and FimE govern its orientation: FimB mediates the inversion in both ON (expression) and OFF (repression) orientations while FimE is biased to the OFF inversion (McClain et al., 1991). This complex mode of regulation in both pathogens is further controlled by additional transcriptional regulators [Reviewed in Schwan (2011) and in Kolenda et al. (2019), tightening the rope around the expression of this costly virulence factor (Sterzenbach et al., 2013).

Biofilm formation is another mode employed by bacterial pathogens to assist in host infection. This multicellular lifestyle benefits bacteria in multiple ways, the most important of which is resistance to external assaults or internal stresses. Indeed, biofilms have been linked to the establishment of recurrent infections and bacterial persistence (Naziri et al., 2021). UPEC can form resilient biofilms through the coordinated expression of several outer membrane appendages, including pili, fimbriae, flagella, and curli (Kaper et al., 2004, Pratt and Kolter, 1998). The T1P plays important roles in this context, allowing UPEC to form biofilms on both abiotic surfaces such as medical supplies and urinary catheters (Wang et al., 2018), and in 
host tissues, such as the bladder epithelium where specialized biofilms called intracellular bacterial communities (IBCs) cause chronic infections (Wright et al., 2007).

Recently, trans-encoded small non-coding RNAs (sRNAs) have emerged as potent regulators of gene expression in various bacterial species (Hör et al., 2020). By partially base pairing with various target mRNAs and regulating their expression at the post-transcriptional level, these non-coding RNAs (ncRNAs) govern various aspects of bacterial physiology (Nitzan et al., 2017), with various roles described in bacterial virulence and biofilm formation (Sy and Tree, 2021, Chambers and Sauer, 2013). For instance, EHEC GImY and GImZ sRNAs promote the formation of A/E lesions through induction of the T3SS effector EspFu, and diminish the expression of other T3SS effectors (Gruber et al., 2014). In Salmonella, the sRNA PinT coordinates the expression of SPI-1 and SPI-2 (Salmonella pathogenicity islands 1 and 2) T3SS virulence factors (Westermann et al., 2016) allowing the pathogen to switch from its invasive to its persistent infective mode. Salmonella CpxQ sRNA inhibits fimA expression through direct base-pairing with the fimA mRNA, controlling T1P expression under conditions of membrane stress (Chao and Vogel, 2016). In E. coli, various sRNAs have been shown to affect T1P expression through the direct inhibition of fimA or fimB, such as the sRNAs RybB and MicA (Bak et al., 2015). These sRNAs often require the RNA chaperone Hfq for generation, stability, and function (Santiago-Frangos and Woodson, 2018). In recent years, similar roles have been ascribed to ProQ, a FinO-family member (Smirnov et al., 2017). While these chaperones are critical for sRNA stability and function, examples of sRNA independence exist in Gram-positive species. For example, Mycobacterium tuberculosis $6 S$ sRNA acts independently of chaperone proteins to coordinate cell division and DNA replication (Mai et al., 2019), teasing the possibility that chaperones can be dispensable for some regulatory circuits.

Previously, our deep sequencing analysis of growth phase-dependent sRNAs in $E$. coli revealed the abundant expression of an SRNA, SRNA_35, in the stationary phase (Raad et al., 2021). This sRNA has also been recognized in previous sequencing studies (Kawano et al., 2005, Ghosal et al., 2015). Here, we report the first functional characterization of this 35-nucleotide sRNA that we rename to fimR2 for fim operon-derived SRNA as it derives from the fimA-fiml intergenic region in $E$. 
coli and $S$. enterica. This operon has been shown by others to encode another sRNA, dubbed fimR, which however derives from a different location within the fim operon and is thus completely independent of fimR2 (Pichon et al., 2012). fimR2 overexpression in exponential phase, a growth phase during which this SRNA is normally undetectable, significantly causes biofilm formation, alters the outer membrane architecture, and switches the bacterial population to stationary phase. Through various genetic and biochemical approaches, we show that these phenotypes are due to the fimR2-mediated regulation of various targets involved in stationary phase biology and motility, directly through base-pairing with target mRNAs, and indirectly, through the sequestration of the translational regulator CsrA. Interestingly, overexpression of the Salmonella variant, fimR2S, in E. coli causes biofilm formation, potentiates the invasiveness of $S$. enterica, and promotes the expression of a T3SS-chaperone. In sharp contrast to most bacterial trans-acting sRNAs, we show that fimR2 acts independently of RNA matchmakers such as $\mathrm{Hfq}$ and ProQ and accumulates through the RNase E-dependent cleavage of fimAICDFGH. We thus propose an example of a trans-acting sRNA in Gramnegative bacteria that does not require an RNA chaperon for its function. This work positions fimR2 as a master regulator of gene expression under stationary phase, employing multitasking to coordinate biofilm formation and virulence.

\section{Results}

fimR2 is abundantly expressed in various $E$. coli strains in a phase-dependent manner.

We previously sequenced the small E. coli transcriptome and identified several sRNAs that are differentially expressed during stationary phase (Raad et al., 2021). One of these sRNA candidates is a 35-nucleotide-long ncRNA (initially dubbed sRNA_35) whose sequence maps to the intergenic space between fimA and fiml. These two protein-coding genes are members of the fim operon encoding the components of T1P. Due to its genomic context, we renamed sRNA_35 to fimR2 for fim operon-derived sRNA. We were intrigued by the abundant expression of fimR2 in stationary phase (Figure S1A) knowing that fimAICDFGH is not expressed in this phase as previously reported (Dove et al., 1997). Indeed, we confirmed that the 
phase-dependent expression of fimR2 is coupled to the concomitant downregulation of fimAICDFGH expression (Figure S1A).

The conservation of fimR2 across various $E$. coli strains and within enteric bacteria (Figure S1B) suggests a role for this sRNA resembling that seen in the domesticated laboratory strain, K12. Thus, we evaluated the expression of this SRNA by northern blotting in five extended spectrum beta-lactamases (ESBL)-producing $E$. coli strains derived from healthy donors (Moor et al., 2021) (Figure S1C). All five strains retain the genomic sequence of fimR2, while four strains expressed the sRNA in stationary phase to varying extents in comparison to the $\mathrm{K} 12$ laboratory strain. Extending our experiments also to pathogenic E. coli strains revealed an abundant expression of fimR2 in a verrotoxin-producing E. coli (VTEC) and two UPEC strains in a phase-dependent manner, peaking in late stationary phase (Figure S1D). Taken together, these findings suggest that the fimR2 abundant expression in stationary phase is a global occurrence that likely plays important roles in this context.

\section{fimR2 is an RNase E-dependent SRNA}

The abundant expression of fimR2 in stationary phase of $E$. coli raises questions about the mechanism of its biogenesis. As fimR2 is expressed in stationary phase, its expression could be governed by the alternative sigma factor RpoS which regulates the transcription of several genes in stationary phase (Hengge-Aronis, 2002). However, northern blot analysis showed an increase in abundance of fimR2 following rpoS deletion (Figure S2A) suggesting that this SRNA is not a primary transcript. Furthermore, expression of fimR2 was not diminished by a fimA deletion (Figure S2B) which abolishes a predicted internal transcription start site (TSS) (Thomason et al., 2015), suggesting that fimR2 expression does not depend on this TSS for expression.

These findings indicated fimR2 as a processing product from the fimAICDFGH primary transcript. If this is the case, the expression of fimAlCDFGH, which is governed by the two recombinases FimB and FimE (McClain et al., 1991), is a prerequisite for fimR2 biogenesis. Knockout of FimB, which allows both ON and OFF inversions to take place, abolished fimR2 expression in stationary phase (Figure S2C). In the absence of FimB, FimE directs fims to the OFF orientation and 
therefore fimAICDFGH cannot be expressed and fimR2 not processed. However, the knockout of the phase-OFF-specific recombinase FimE leads to a prominent upregulation of fimR2 in both exponential and stationary phase (Figure $\mathbf{S 2 C}$ ). Additionally, fimR2 processing intermediates with various sizes accumulated exclusively in exponential phase upon fimE deletion, but not in stationary phase (Figure S2C). In the absence of FimE, FimB inverts fimS in both orientations without being antagonized by FimE, causing prominent expression of fimAlCDFGH (data not shown). These experiments suggested that the biogenesis of fimR2 necessitates the prior expression of fimAICDFGH and that fimR2 is most likely cleaved from this transcript by an endonuclease specifically in stationary phase.

We next sought to determine the identity of the RNase(s) responsible for fimR2 processing and release in stationary phase. For this purpose, RNA was extracted from several RNase deletion strains and fimR2 expression was evaluated by northern blotting. Knockout of RNase I, PNPase, RNase G, RNase R, RNase HI or RNase HII did not affect fimR2 levels during stationary phase (Figure S2D). Similarly, a mutation that impairs RNase III function (Dasgupta et al., 1998) did not affect fimR2 abundance (Figure S2E). These experiments suggested that these nucleases are not involved in fimR2 biogenesis.

A key endoribonuclease that is involved in mRNA turnover in stationary phase and in sRNA biogenesis is the endoribonuclease $E$ (RNase E) (Hör et al., 2020). RNase E cleavage generates RNA molecules with a monophosphate at the 5'-end (Chao and Vogel, 2016). To determine the nature of fimR2 5 '-end, we subjected total RNA to a terminator exonuclease (TEX) treatment that preferentially degrades RNA molecules with a 5'-monophosphate, such as rRNA. fimR2 was sensitive to TEX treatment, but not an in vitro transcribed tRNA fragment (tRF) with a 5'-triphosphate (Figure 1A), suggesting that fimR2 is processed and retains a 5'-end signature typical for RNase E cleavage. To investigate the putative involvement of RNase $E$ in fimR2 processing, an RNase E-temperature sensitive strain was employed that expresses a fully active RNase at $30^{\circ} \mathrm{C}$ and an RNase with impaired function at $43^{\circ} \mathrm{C}$ (Babitzke and Kushner, 1991). Upon switching the stationary phase-bacterial culture from the permissive to the non-permissive temperatures, fimR2 was depleted in $r n e 3071^{\text {ts }}$ strain but not in the K12 strain (Figure 2B). Simultaneously, the precursor of the RNase Edependent sRNA ArcZ (Updegrove et al., 2018), accumulated in the rne $3071^{- \text {ts }}$ strain 
at the non-permissive temperature. This confirmed the role of RNase $\mathrm{E}$ in fimR2 processing. To further corroborate these findings, we used the purified catalytic domain of RNase $E$ (Callaghan et al., 2005) in an in vitro cleavage assay. For this, a fimR2 precursor containing extensions on both ends was in vitro transcribed and then RppH-treated to generate RNase $\mathrm{E}$ cleavage templates containing a monophosphate at the 5'-end (Jiang and Belasco, 2004). Incubation of the precursor with increasing amounts of RNase $E$ led to the cleavage of the precursor to an intermediate size of 40 nt (Figure 2C).

Taken together, these findings suggest that RNase $\mathrm{E}$ governs fimR2 biogenesis from the parental fimAICDFGH transcript in stationary phase. The appearance of the 40nt intermediate in the in vitro cleavage assay suggested fimR2 to be trimmed to its final size by another yet to be identified RNase, or that in vivo-derived fimR2 is posttranscriptionally modified.

\section{fimR2 promotes stationary phase-dependent biofilm formation}

What kind of functions is the RNase E-processed fimR2 involved in? We previously reported that the ectopic overexpression of this sRNA in exponential phase, its alienated phase, upregulates the expression of rpoS (Raad et al., 2021), the alternative RNA Polymerase sigma factor governing gene expression in stationary phase. This suggested that the sRNA is important for stationary phase-specific phenomena. To gain insight into possible fimR2 functions, we ectopically expressed this sRNA in an inducible manner during exponential phase (Raad et al., 2021). Strikingly, fimR2 expressing strains started to dramatically aggregate in culture following $1 \mathrm{~h}$ of overexpression at static conditions, and beyond $2 \mathrm{~h}$ at shaking conditions, coupled to the clearing of the LB medium, a phenotype with no counterpart in the control strain (Figure 2A). Furthermore, the aggregated cellular suspension forms resistant biofilms at the bottom and edges of the flask, suggesting that fimR2 overexpression causes biofilm formation. To inspect this phenotype further, we performed scanning electron microscopy (SEM) of the fimR2 overexpressing strain grown in microtiter plates mounted with coverslips. SEM revealed significant crowding of the coverslip with multiple embedded cells for the fimR2 overexpression strain, and only a modest bacterial population for the control 
strain, which overexpressed an unrelated RNA sequence (Figure 2B). We further corroborated these findings using quantitative biofilm assays and a gentler qualitative biofilm assay of bacterial cells grown on coverslips. Both approaches confirm that fimR2 overexpression causes biofilm formation (Figure 2C, D). As bacterial cells in stationary phase often form biofilms (Markova et al., 2018), we next inspected the biofilm forming potential of wild-type (WT) and fimR2 genomic deletion ( $\Delta$ fimR2) strains in stationary phase. Indeed, both WT and $\Delta$ fimR2 strains formed biofilms in stationary phase (Figure 2C, D) while $\Delta$ fimR2 showed markedly reduced biofilm formation potential compared to the WT strain. Genetic complementation of fimR2 deletion ( $\triangle$ fimR2/fimR2) through ectopic expression of this sRNA restores biofilm formation to WT levels (Figure 2C, D). Taken together, these experiments suggested that fimR2 is an important contributor to biofilm formation in stationary phase.

To further validate the involvement of fimR2 in this phenotype, we carried out mutagenesis studies. A careful observation of the aligned fimR2-like sequences in the fimA-fim/ region from various $E$. coli strains and other enteric bacteria suggests that the sequence is highly conserved, with nucleotides 18 to 31 having the least variations (Figure S1B). MFold analysis predicted this region to forming a stem-loop secondary structure (Figure S3A). Mutations that individually disrupt the stem or the loop of this hairpin destabilized the sRNA (Figure S3B) and consequently eliminated the biofilm formation (Figure S3C, D). A fimR2 compensatory mutant that allows the re-establishment of the stem-loop structure was stably expressed (Figure S3B) and functional in eliciting biofilm formation albeit to a lesser extent than the wild-type sequence (Figure S3C, D). Interestingly, the fimE deletion strain, a strain constantly transcribing the fimAICDFGH operon, phenocopied fimR2 overexpression in exponential phase and caused prominent biofilm formation (Figure S2F, G). We conclude that this secondary structure likely exists in vivo and contributes to fimR2 stability, and thus its ability to propagate biofilm formation.

\section{fimR2 alters bacterial outer membrane architecture}

The dramatic biofilm formation phenotype seen upon fimR2 expression is expected to be accompanied with an altered gene expression pattern that will remodel the 
outer membrane architecture and impact proteinaceous appendages displayed to the outer milieu, such as flagella, fimbriae, and pili. To evaluate this hypothesis, we used scanning electron micrography of $E$. coli bacterial pellets from planktonic growth stages. SEM revealed that bacterial cells derived from exponential phase of growth were elongated and displayed flagella, fimbriae, and pili (Figure 3A). In contrast, bacterial cells in stationary phase were more ovoid and naked, displaying curli fimbriae and PGA (poly- $\beta$-1,6-N-acetyl-d-glucosamine) (Boehm et al., 2009) (Figure 3B). Strikingly, fimR2 overexpressing strains in exponential phase displayed pronounced aggregation and PGA synthesis and adopted a stationary phase-like morphology while the control overexpressing strains resembled exponentially growing cells (Figure 3C, D). $\triangle$ fimR2 and $\triangle$ fimR2/fimR2 strains significantly diverged in their morphologies from one another, although both strains were in stationary phase. $\triangle$ fimR2 exhibited exponential phase-like morphologies with extensive flagellation, while $\Delta$ fimR2/fimR2 mimics wild-type stationary phase physiology (Figure 3E, F). The characteristic morphologies of cells in exponential and stationary phase are in agreement with what has been previously reported (Serra et al., 2013), showing that our distinct results were not artifacts of cell fixation. These SEMs thus showed that fimR2 expression and fimR2 deletion resulted in opposing morphologies on the extreme ends of a spectrum that separates stationary from exponentially growing cells, with control overexpressing and fimR2 compensation strains lying in the middle and behaving like their wild-type counterparts in their respective stages. In this manner, fimR2 appeared to trigger a significant outer membrane architecture remodeling, a critical process in the transition to stationary phase.

\section{fimR2 regulates cell motility and stationary phase biology}

To test the hypothesis that fimR2 binds putative mRNA targets via its predicted single-stranded region (Figure S3A), a bioinformatic target prediction tool was employed (Wright et al., 2014). Guided by the observed fimR2-dependent phenotype (Figures 2 and 3), a subset of the predicted 200 targets in K12 strain were selected for experimental validation. Multiple predicted targets (fliJ, fliG, flil, and fliR) are mRNAs coding for flagellar biosynthesis proteins (Figures 4A and S4A-C) (Minamino and Namba, 2004) three of which (fliJ, fliG, and flil) are part of the same 
operon (Fitzgerald et al., 2014). Additionally, one of the top candidates, hofQ, (Figure S4D) is a poorly characterized importer of exogenous DNA to be used in catabolic reactions that provide more nutrients to the starved cells in stationary phase (Palchevskiy and Finkel, 2006). First, we evaluated the expression pattern of these putative targets by RT-qPCR analysis under different conditions. The flagellar biosynthesis operon and fliR were downregulated upon fimR2 overexpression during exponential growth, a pattern resembling the canonical expression of these messages in stationary phase of growth (Figures 4B and S4A-C). hofQ was upregulated upon fimR2 overexpression during exponential phase (Figure S4D). The genomic deletion of fimR2 ( $\triangle$ fimR2) perturbed the stationary phase expression pattern of all candidates while in the fimR2 complementation ( $\triangle$ fimR2/fimR2) strain the stationary phase-specific expression was restored (Figures 4B and S4A-D). These findings suggested these mRNAs as genuine fimR2 targets. As such, the presence of fimR2 potentially affects the stability of these mRNAs either negatively (fliJ, fliG, flil, and fliR) or positively (hofQ).

Next, we evaluated if fimR2 regulates these targets through direct base-pairing at the post-transcriptional level. For this purpose, the first $30 \mathrm{nt}$ of fliJ, including the predicted target site, were fused to red fluorescent protein (RFP) and fluorescence was monitored following in the absence or presence of ectopically expressed fimR2 in the $\Delta$ fimR2 strain. As additional specificity control, fimR2-CU was tested, which is a stably expressed fimR2 mutant defective in triggering biofilm formation (Figure 4C). Reporter assays showed that fimR2 overexpression downregulated fliJ-RFP expression by almost 80\% (Figure 4D). As fimR2 overexpression caused cell aggregation and biofilm formation (Figure 2A), fluorescence measurements were additionally validated by western blotting (Figure 4D), and these experiments fully confirmed the fluorescence data.

Taken together, these findings showed that fimR2 acts as a trans-acting sRNA, inhibiting the expression of fliJ and potentially other transcripts involved in motility (fliG, flil, and fliR), thereby eliciting biofilm formation. Concomitantly, fimR2 promotes the expression of $h o f Q$, providing means for the stressed bacterium to import foreign DNA for catabolic reactions. 


\section{fimR2 interacts with CsrA}

Bacterial sRNAs are usually stabilized by RNA chaperones, such as Hfq or ProQ, for further assisting in sRNA-target interactions (Hör et al., 2020). We thus evaluated the dependence of fimR2 on either chaperone by monitoring its stability following $h f q$ and $p r o Q$ deletions. Northern blot analysis showed that fimR2 abundance was unaffected in stationary phase in the absence of either chaperones (Figure S5A). Furthermore, fimR2 was also not recovered in RIL-seq analyses of both chaperones (Melamed et al., 2020). Taken together, these observations suggested that, unlike most trans-encoded sRNAs, fimR2 acts independently of both Hfq and ProQ.

Another prominent bacterial chaperone protein is the translational regulator CsrA that is involved in a plethora of cellular activities (Pourciau et al., 2020). Interestingly, a recent CLIP-seq analysis revealed that CsrA interacts with both the fimA sequence and the intergenic fimA-fiml region (Potts et al., 2017). As the latter is a short region composed predominantly of the fimR2 sequence, we hypothesized that CsrA is interacting with the sRNA. CsrA favorably binds GGA motifs, with a preference to those located in secondary structures (Potts et al., 2017). The fimR2 sequence contains two GGA motifs with the first located in the single-stranded region, and the second in the loop structure (Figure S5B), suggesting that the sRNA could use both motifs to interact with a CsrA dimer. To validate this potential interaction, we expressed and co-immunoprecipitated his-tagged CsrA in stationary phase and revealed a striking enrichment of fimR2 in the eluted fractions (Figure 5A). The CsrA-interacting sRNA CsrB (Liu et al., 1997) was also recovered in the same fractions (Figure 5A). However, full-length $t R N A^{G l y}$ and its 5'-tRNA fragment, a stationary-phase enriched sRNA that we previously recovered (Raad et al., 2021), were both largely depleted from these fractions (Figure 5A) thus highlighting the specificity of the experimental system. Taken together, these pulldown data confirmed that fimR2 and CsrA interact in vivo.

To corroborate these findings, we carried out electrophoretic mobility shift assays (EMSA) with in vitro transcribed and 5'-end labelled fimR2 and purified CsrA. These EMSA experiments showed that fimR2 upshifts with increasing concentrations of purified CsrA (Figure 5B). Mutations of the GGA motif in the fimR2 stem-loop region, but not in its single-stranded region (ssRegion), abolished association with CsrA 
(Figure 5C, D). Taken together, these experiments suggested that CsrA binds fimR2 at the stem-loop region.

We next wondered what purpose this interaction is fulfilling. As fimR2 did not associate with $\mathrm{Hfq}$ or ProQ (Figure S5A), we hypothesized that CsrA may be stabilizing the sRNA. As the deletion of CsrA is detrimental to bacterial growth in LB (Timmermans and Melderen, 2009), we thus altered cellular CsrA availability to test fimR2 dependence on the chaperone. The CsrA translational regulator is sequestered from its target through its interaction with sRNAs CsrB and CsrC as both sRNA are heavily folded and contain multiple GGA motifs that entrap CsrA (Liu et al., 1997, Weilbacher et al., 2003). These sRNAs are degraded by RNAse E through the adaptor activity of CsrD (Suzuki et al., 2006). As such, deletion of CsrD upregulated CsrB and CsrC expression (Figure S5C) and thus limited the pool of available free CsrA dimers in the cell. Nonetheless, fimR2 expression was not perturbed upon CsrD deletion (Figure S5C), suggesting that the sRNA interaction with CsrA is not critical for its stability. Subsequently, deletion of either CsrB or CsrC sRNAs or both would release free CsrA dimers in the cell, however neither deletion significantly boosted fimR2 expression (Figure S5D). Furthermore, the addition of purified CsrA to in vitro cleavage reactions did not enhance the RNase E-dependent processing of the fimR2 precursor (Figure 1D). We thus concluded that despite the fimR2/CsrA interaction formation, CsrA does not stabilize fimR2 in vivo and thus this interaction must be fulfilling another distinct function.

\section{fimR2 sequesters CsrA from its targets}

The interaction of CsrA with sRNA partners have largely been associated with antagonizing mechanisms with the sRNAs sequestrating the translational regulator from its targets (Liu et al., 1997, Weilbacher et al., 2003, Jørgensen et al., 2013) or the sequestration of the sRNA from its targets by the chaperone (Potts et al., 2017). We thus considered the hypothesis that fimR2 is sequestering CsrA from its targets, rather than relying on the chaperone for finding and binding target mRNAs. Interestingly, SEM showed depletion of T1P in conditions giving rise to prominent fimR2 expression (Figure 3B, D, E). Under similar conditions, RT-qPCR analysis revealed significant downregulation of $\operatorname{fimA}$ (Figure S6A) and other individual 
members of the fim polycistron (Figure S6B-G). As the sequence of the fimAICDFGH operon and its 5'-UTR do not possess predicted base-pairing sites with fimR2, and fimR2 ectopic overexpression dramatically downregulates T1P (Figures 3D and S6A-G), we proposed that fimR2 could regulate the expression of these transcripts indirectly. CsrA has been shown to stabilize fimAICDFGH by interaction with fimS (Mitra et al., 2013). In this manner, the interaction of fimR2 with CsrA could be antagonizing this stabilization of the fim transcript, suggesting that fimR2 is sequestering CsrA and antagonizing its activity.

Prominent morphological features seen following fimR2 overexpression on SEM include increased PGA synthesis and a dramatic loss of flagellation (Figure 3D). The secretion of PGA is done by the coordinated actions of the members of the pgaABCD operon (Itoh et al., 2008). CsrA downregulates the expression of this transcript by allowing premature rho-dependent transcription termination (FigueroaBossi et al., 2014). RT-qPCR analysis showed dramatic upregulation of pgaA upon fimR2 overexpression (Figure 5E), suggesting that binding of fimR2 to CsrA prevented the latter from downregulating pgaA. In parallel, CsrA promotes flagellar motility by stabilizing the fIhDC transcript and shielding it against RNase $E$ cleavage (Yakhnin et al., 2013). RT-qPCR analysis of flhDC shows repression upon fimR2 overexpression (Figure 5F) presenting the opposite scenario of the regulation by CsrA. These two experiments present so far unknown examples of CsrA antagonisms by fimR2 and suggest that fimR2 sequesters CsrA away from its targets in similar fashions as reported for CsrB, CsrC, and other sRNAs (Pourciau et al., 2020). Furthermore, this sequestration model is compatible with the observed prominent biofilm formation upon fimR2 overexpression (Figure 2A-D), resembling those seen upon CsrA deletion (Jackson et al., 2002)

\section{fimR2 promotes S. enterica invasion}

As the sequence of the SRNA is conserved in many Escherichia and Shigella species (Figure S1B), we wondered if fimR2 is present in pathogens from the Salmonella genus. In a recent study, RNase $\mathrm{E}$ was shown to cleave near the fimA stop codon in S. enterica serovar Typhimurium (SL1344, SB300) (Chao et al., 2017) generating a small transcript whose sequence is similar to that of E.coli fimR2 
(Figure 6A). We refer to this putative sRNA as fimR2S to denote it as the fimR2 variant in Salmonella. Northern blot analyses demonstrated the expression of a 30 nt RNA in late stationary phase in the assayed Salmonella strains (Figure 6B). This finding and the reported RNase E cleavage site within the $\operatorname{fim} A$ transcript suggested a similar phase-dependent cleavage occurring in stationary phase and releasing fimR2S from the fimA transcript. S. enterica often express T1P under laboratory growth conditions and under static conditions (Hansmeier et al., 2017). This suggests that the lower abundance seen for fimR2S as compared to $E$. coli is due to the continuous T1P expression in these Salmonella strains.

To understand the potential functions of fimR2S, we overexpressed it in both $S$. enterica and $E$. coli followed by tracking the phenotypic changes. To this end, we conducted 5'- and 3'-RACE experiments to map the exact ends of this sRNA. Only 5'-RACE experiments were successful (Figure 6A) and showed a lower abundance, longer transcript (fimR2S-L) that retains part of the fimA coding sequence, and a shorter more abundant form (fimR2S-S) solely generated from the fimA-fiml intergenic space. We thus cloned both forms into an expression plasmid (Figure 6A). To generate the canonical 3'-end of the transcript, we included a portion of the fimA-fiml intergenic space downstream of the two variants, prompting RNAse $E$ to generate the canonical 3'-end of fimR2S or for its potential secondary structure to terminate its expression. Strikingly, overexpression of fimR2S-L, but not fimR2S-S in E. coli caused biofilm formation (Figure 6C) as only the longer variant was processed properly. Overexpression of either fimR2S variants in $S$. enterica did not promote biofilm formation (data not shown). Similarly, the overexpression of the $E$. coli fimR2 in S. enterica (Figure 6D) did not promote biofilm formation. Taken together, these experiments suggested that Salmonella fimR2S mimics fimR2 functions in $E$. coli but the sRNA is not functional in $S$. enterica. Alternatively, fimR2S may be operating in $S$. enterica differently than in E. coli.

S. enterica infectivity largely relies on the secretion of several effectors by the T3SS (Galán, 2021). Considering the effects of fimR2 on biofilm formation (Figure 2D) and outer membrane architecture (Figure 3D) in E. coli, we hypothesized that the sRNA is involved in virulence and used fimR2S in $S$. enterica to evaluate this possibility. SicA is a critical T3SS chaperone that promotes the expression of invasion mediating effector proteins (Tucker and Galán, 2000). Significantly, fimR2S 
overexpression induced sicA-GFP fusion protein (Sturm et al., 2011) in a reporter assay (Figure 6E), suggesting that the Salmonella sRNA is functional in promoting T3SS secretion. Next, we hypothesized that the sRNA could regulate infectivity as it positively regulates T3SS. To test this hypothesis, we infected HeLa cells with wildtype $S$. enterica from both exponential and stationary phase and with the fimR2S overexpression strain (Pfister et al., 2020). Using the SB245 strain, which is invasion deficient as a negative control, we quantified the intracellular bacterial load following treatment with gentamicin, which is membrane impermeable and consequently kills non-invaded extracellular bacteria selectively. According to this invasion assay, fimR2S overexpressing strains were markedly more invasive than either wild-type strains (Figure 6F), suggesting that fimR2S promotes invasion and internalization of bacterial cells into human cells.

\section{Discussion}

In this study we identified and functionally characterized fimR2, an abundant 35 nucleotide-long sRNA specifically expressed in stationary phase of bacterial growth (Figure S1A). To this end, we ectopically overexpressed this sRNA during exponential phase to investigate its potential regulatory effects outside its canonical growth phase context. While the overexpression in exponential phase produced much more sRNA than is normally present in stationary phase (Figure 2C), the observed phenotype (namely regulation of fimbrial and flagellar mRNAs, modulation of outer membrane architecture, and induction of biofilm formation) was comparable to the effects in stationary phase. We report the first functional characterization of this sRNA, and with the generated knowledge we confidently ascribe a master regulatory status to fimR2, an RNase-E dependent sRNA which single-handedly and without the assistance of known RNA chaperones, coordinates motility, biofilm formation, stationary phase biology, and even virulence (Figure 7).

\section{fimR2 orchestrates biofilm formation through multitasking}

fimR2 overexpression instructed bacteria to a rapid transition to a sessile lifestyle (Figure 2A-D). fimR2 orchestrates this complex shift in multiple ways: the sRNA 
upregulated hofq mRNA involved in stationary phase biology (Figure S4D) and downregulated several targets coding for flagellar protein synthesis (Figures 4B, D and S4A-C), explaining the shift from planktonic to sedentary growth stages. In this context, fimR2 appears to act in a similar fashion to other bacterial trans-encoded sRNAs, regulating target mRNAs at the posttranscriptional levels (Nitzan et al., 2017). As the mRNA levels of several predicted targets directly responds to fimR2 varying levels, fimR2 is likely recruiting RNases to degrade certain targets (fliJ, fliG, flil, and fliR) while stabilizing others (hofQ).

In a separate mode of action, fimR2 sequesters CsrA, a known translational regulator of the Type III secretion system, from its target genes, which are involved in bacterial motility and biofilm formation. CsrA affects the levels of flhDC (motility) and pgaABCD (biofilm formation) mRNAs, respectively, by shielding the former from RNase degradation and allowing Rho access to the transcript of the latter (Yakhnin et al., 2013, Figueroa-Bossi et al., 2014). By downregulating flhDC expression (Figure 5F) and upregulating pgaA expression (Figure 5E), fimR2 appears to antagonize these specific CsrA functions. In a similar manner, fimR2 ectopic overexpression downregulated fimA expression (Figure S6A). While the sRNA is processed from the complete fimAICDFGH operon mRNA in stationary phase (Figure 1B, C) and through this mode, the parental transcript is downregulated, fimR2 likely tightens the inhibition on the fim operon by competing for CsrA binding (Mitra et al., 2013).

Finally, fimR2 overexpression caused the upregulation of $r p o S$, the stationary phasedependent RNA polymerase sigma factor (Raad et al., 2021). While this inductive effect is likely indirect, as we do not observe a putative base-pairing site for fimR2 within the rpoS mRNA sequence, it explains the propensity of bacterial cells to form biofilms (Figure 2A) and to adopt stationary phase-like morphology (Figure 3B, D, F). Future work is needed for a better understanding of the mechanism by which fimR2 affects rpoS expression.

\section{Efficiency and sustainability in bacterial regulatory networks}

The simultaneous modulation of biofilm formation, motility, stationary phase biology, and even virulence (Figure 7) is not a trivial task. The success of fimR2 in these 
strenuous activities and its ability to navigate several branches within a complex regulatory network can be attributed to two distinct features: fimR2 dual mode of function and its abundance. Bacterial trans-encoded sRNAs are efficient and potent regulatory molecules as they typically employ their single-stranded regions to basepair and regulate various targets mRNAs at the post-transcriptional level (Nitzan et al., 2017). Indeed, the range of fimR2 mRNA targets is very diverse (Figure S4A-D) and includes transcripts coding for flagellar proteins and porins, among many others. Another mode by which fimR2 exhibits utmost efficiency is through its sequestration of the translational regulator CsrA (Figure 5E, F). CsrA itself is a master regulator of gene expression, governing diverse cellular processes including motility, biofilm formation, virulence, quorum sensing, metabolism, and oxidative stress (Pourciau et al., 2020). By sequestering CsrA from mediating its cellular functions, fimR2 automatically gains regulatory access to the CsrA-specific expression network and navigates its intricate web, remodeling its fibers in an antagonistic manner. Such a dual regulatory function has also been attributed to other sRNAs such as McaS (Jørgensen et al., 2013) that simultaneously regulates target mRNAs and sequester CsrA. Furthermore, CsrA has been shown to interact with other sRNAs (Potts et al., 2017). With the existence of these various parallel examples, it is now more evident that bacterial species have evolved efficient and elegant regulatory modes to rapidly adapt to unpredictable environments.

fimR2 abundance is another feature contributing to its potent effect. Indeed, the sRNA is far more abundant than its peers ( $A r c Z$ for example, Figure 1B) explaining its ability to tightly modulate various targets simultaneously. Furthermore, fimR2 is more abundant than CsrB and CsrC (Figure S5C, D). While these two sRNAs possess multiple GGA motifs to entrap CsrA in their secondary structures, the single GGA motif on the highly abundant fimR2 molecule is sufficient to efficiently sequester CsrA (Figure 5A). While the expression of such an abundant RNA molecule would normally entail overwhelming energy expenditure, fimR2 biogenesis constitutes another efficient mechanism. Culminating in vivo and in vitro evidence revealed that RNase $\mathrm{E}$ processes fimR2 from the parental fim transcript (Figure 1BD). As the accumulation of this sRNA occurs in stationary phase, the processing event likely overlaps with fimAICDFGH mRNA turnover during the same growth phase. fimAICDFGH is very abundant in E. coli (Figure S1A) and in Salmonella (Sterzenbach et al., 2013), explaining the abundance of the resulting sRNA. 


\section{fimR2 is an RNase-E dependent sRNA}

What signals are required for this specific fimR2 cleavage to occur locally and temporarily are still elusive. RNase E determinants include AU-rich sequences, stem-loop structures, and transcripts with 5'-monophosphates (Updegrove et al., 2018). The fimA deletion strain used in this study retains a portion of the fimA ORF at the 3'-end, near the stop codon (Baba et al., 2006). As this knockout did not reduce fimR2 expression (Figure S2B), we postulate that any sequence-specific motifs or secondary structures required for fimR2 processing by RNase $E$ are present in its vicinity. That a 40-nt intermediate was generated upon in vitro RNase $E$ cleavage of a fimR2 precursor (Figure 1C, D) suggests a role for another RNase in complete fimR2 biogenesis. While our consideration of other RNases (Figure S2D,

E) was not comprehensive, the depletion of fimR2 in vivo upon RNase $\mathrm{E}$ deactivation (Figure 1B) speaks against additional RNases being involved. Furthermore, in vitro cleavage assays with total cell lysates generated the same 40-nt intermediate (data not shown) suggesting the in vitro precursor transcript lacking crucial determinants for complete processing, such as post-transcriptional modifications or the establishment of correct three-dimensional architecture.

Finally, the secondary structure adopted by fimR2 resembles that of an intrinsic terminator (Figure S5B). Indeed, a similar structure has been proposed to serve as an intrinsic terminator for fimA expression (Klemm, 1984). As such, a single processing event occurring at the 3 '-end of the fimA transcript, and thus at the 5 '-end of the fimR2 sRNA, would have to take place to release the sRNA from the parental transcript for final processing by RNase E. This scenario can explain the observed proper transcription termination in the fimR2 and fimR2S overexpression experiments (Figures S3B and 6C, D), and the appearance of the 40-nt intermediate (Figure 1C, D).

\section{fimR2 does not associate with $\mathrm{Hfq}$ or ProQ}

fimR2 is a functional sRNA possessing regulatory roles independently of the known RNA chaperones Hfq and ProQ (Figure S5A). This finding is surprising as most trans-encoded regulatory sRNAs in bacterial species require a chaperone to 
maintain their stabilities or to anneal to their target mRNAs (Hör et al., 2020). In variance, fimR2 interacts with the bacterial translational regulator CsrA (Figure 5A). CsrA seems to bind fimR2 via its predicted stem-loop structure (Figure $5 \mathbf{C}$ ) which is in agreement with the reported preference of CsrA to bind GGA motifs in stem-loop structures (Potts et al., 2017). The interaction with CsrA does not seem to stabilize the sRNA as depletion of the pool of available CsrA molecules did not perturb fimR2 abundance (Figure S5C). The opposite is also true as the increase of CsrA molecules did not enhance fimR2 stability (Figure S5D). Forming yet another contrasting phenomenon to other sRNAs, fimR2 processing by RNase $E$ did not require a chaperone (Figure 1C) nor did it depend on CsrA (Figure 1D).

Mutagenesis of fimR2 abolished its regulatory functions (Figures S3C, D, and 4C, D). However, only the mutations targeting the predicted secondary structure impaired fimR2 stability (Figure S3B). As fimR2 does not seem to associate with any known RNA chaperon, this secondary structure may be in fact the only factor required for the sRNA stability. In support of this interpretation, unfolded fimR2 was rapidly degraded upon incubation with total cell lysates (data not shown), suggesting that the predicted stem-loop is indeed critical for stability. However, it is possible that fimR2 associates with a so far uncharacterized RNA chaperon in vivo, a hypothesis compatible with the observed upshift patterns seen in crosslinking experiments (Figure S5E).

\section{fimR2 contributes to virulence}

This work illustrates several modes by which fimR2 promotes stationary phase biology (Figure S4D), biofilm formation (Figures 2B-D and 5E) and suppresses bacterial motility (Figures 3D, 5F, and S4A-C). All three processes have been shown to be important for bacterial virulence. Bacteria display increased expression of virulence genes during stationary phase (Navarro Llorens et al., 2010). Pathogens also use their flagella to swim towards sites of infection (Josenhans and Suerbaum, 2002). They form biofilms as a form of resistance against antimicrobial treatments and persistence within hosts (Naziri et al., 2021). Furthermore, bacterial biofilms on medical equipment significantly contribute to infections (Wang et al., 2018). In this context, we noted that biofilms resulting from fimR2 overexpression (Figure 2B) or 
fimE deletion (Figure S2F, G) were extremely resistant to mechanical stress (centrifugation and pipetting during SEM preparation) as well as chemical stress through ethanol and SDS treatment. With the contribution of fimR2 to these processes, it is thus logical to posit that fimR2 likely contributes to disease establishment. In fact, CopraRNA analysis predicted several targets to be involved in lipopolysaccharide (LPS) synthesis, suggesting that fimR2 could modulate LPS synthesis and display, a prerequisite for disease establishment.

To investigate fimR2 role in virulence, we use fimR2S, the fimR2 homologue of $S$. enterica as a proxy. While fimR2S overexpression in $S$. enterica did not cause detectable biofilm formation (data not shown), it promoted biofilm formation in $E$. coli (Figure 6C) suggesting that fimR2S is functional and can substitute for fimR2 in $E$. coli. Though E. coli fimR2 overexpression in S. enterica was successful (Figure 6D), it did not contribute to biofilm formation either. It is tempting to assume that fimR2S operates in $S$. enterica in different modes although it is generated from the same genomic context and likely through similar RNase $E$ cleavage. Because of the involvement of fimR2 in biofilm formation (Figure 2A-D), we hypothesized that the SRNA or its homologue in $S$. enterica, fimR2S, would be involved in virulence. Indeed, fimR2S overexpression in S. enterica upregulates sicA expression (Figure 6E), paralleling the upregulation of this T3SS-chaperone upon CsrA mutation (Hung et al., 2019). And indeed, fimR2S overexpressing strains were clearly more infectious of HeLa cells than their wild-type counterparts (Figure 6F). These two experiments suggested that fimR2S can promote $S$. enterica virulence via a currently unknown mechanism. Like fimR2, fimR2S also retains two GGA motifs (Figure 6A) that could be employed to interact with CsrA. Furthermore, the 5'-UTR of the Salmonella fim transcript has been reported previously to interact with CsrA (Sterzenbach et al., 2013). Based on these similarities, we hypothesized that in $S$. enterica, fimR2S can function to sequester CsrA from its targets in a comparable manner as in E. coli. While we did not investigate the association between CsrA and the sRNA in this species, fimR2S promotion of virulence suggests potential sequestration of CsrA. As CsrA plays critical roles in regulating T3SS effectors (Altier et al., 2000, Lou et al., 2019) and thus disease establishment, it is thus tempting to assume that the fimR2S-dependent induction of $\operatorname{sic} A$ occurs through the sequestration of CsrA. More experimental work is needed to validate these hypotheses. 
Finally, the growth phase dependent expression of fimR2 in the $E$. coli clinical isolates ESBL, VTEC, and UPEC strains (Figure S1C, D) suggests a role for the sRNA in these strains. K12 and UPEC strains show similar predicted targets for fimR2 regulation suggesting that the sRNA could potentially play similar regulatory functions in the pathogenic strain. Furthermore, the dependence of UPEC on the T1P suggests that fimR2 might play important roles in dictating the expression of the conserved fimAICDFGH operon. The expression of fimR2 in pathogenic E. coli then can remodel the outer membrane architecture by inhibiting T1P expression and promoting that of other adhesins. In this context, the use of UPEC as a model to study fimR2 expression during invasion can provide better understanding of the function of the sRNA in disease.

In summary, this study revealed a so far functionally uncharacterized 35 nucleotides long non-coding RNA, named fimR2, to serve as post-transcriptional regulator in $E$. coli and Salmonella. fimR2 is a stationary phase-specific sRNA that modulates several target mRNAs with the result of increased biofilm formation, reduced motility and enhanced infectivity. fimR2 might play an even more intricate role as global regulator on the population level during infections, as it has been demonstrated to be one of the most abundant secreted RNA molecules in outer membrane vesicles (Ghosal et al., 2015). Therefore our study can be regarded as steppingstone for future dedicated work on fimR2 for elucidating even more elaborate mechanisms by which this tiny RNA molecule weaves its regulatory network.

\section{Acknowledgments}

We would like to thank Alexander Mankin (UIC, Chicago) for providing KEIO strains, Eric Massé (University of Sherbrooke) for sharing the rne3071-ts strain, Ben Luisi (University of Cambridge) for sharing active RNE-NTD fractions, and Markus Hilty (IFIK, Bern) for providing E. coli human and pathogenic strains. We would also like to thank Andrew Hemphill (VetSuisse, Bern) for providing expertise and reagents for SEM, and Beatrice Frey (DCBP, Bern) for assisting with the Zeiss Microscope. This work was funded by the Swiss National Science Foundation (grant 310030-197515 to N.P). Additional support from the NCCR "RNA \& Disease" (to N.P.) and the NCCR 
"Microbiomes" (to S. H.) funded by the Swiss National Science Foundation is acknowledged. D.T. was a recipient of a Helmut-Horten-Foundation grant.

\section{Author Contribution}

Conceptualization, N.R. and N.P.; Methodology, N.R., T.D. and S.H.; Formal Analysis, N.R.; Investigation, N.R.; Resources, N.R.; N.P.; T.D. and S.H.; Writing Original Draft, N.R.; Writing - Review and Editing, N.P., N.R., and S.H.; Supervision, N.P.; Funding Acquisition, N.P.

\section{Declaration of interests}

The authors declare no competing interests.

\section{STAR Methods}

\section{RESOURCE AVAILABILITY}

\section{Lead contact}

Further information and requests for resources and reagents should be directed to and will be fulfilled by Norbert Polacek (norbert.polacek@unibe.ch)

\section{Materials availability}

The strains and plasmids generated in this study will be provided upon request.

\section{Data and code availability}

This paper does not report any original code.

\section{EXPERIMENTAL MODEL AND SUBJECT DETAILS}

Strains are included in Table S1 and their conditions of growth are described below. 


\section{Key Resource Table}

\begin{tabular}{|c|c|c|}
\hline REAGENT or RESOURCE & SOURCE & IDENTIFIER \\
\hline \multicolumn{3}{|l|}{ Antibodies } \\
\hline $6^{*} \mathrm{His}, \mathrm{His}-\mathrm{Tag}$ mouse monoclonal antibody & Proteintech & $\begin{array}{l}\text { Catalogue number: } \\
66005-1-\mathrm{lg}\end{array}$ \\
\hline Anti-RFP mouse monoclonal antibody & Rockland & $\begin{array}{l}\text { Number: } 200-301- \\
379 S\end{array}$ \\
\hline IRDye 800CW Goat anti-mouse IgG secondary antibody & Licor & AB_621842 \\
\hline \multicolumn{3}{|l|}{ Bacterial and virus strains } \\
\hline \multicolumn{3}{|l|}{ See Table S1 } \\
\hline \multicolumn{3}{|l|}{ Critical commercial assays } \\
\hline Wizard $^{\otimes}$ SV Gel and PCR Clean-Up & Promega & A9282 \\
\hline Wizard $^{(\Theta)}$ Plus SV Minipreps DNA Purification System & Promega & A1460 \\
\hline SuperScript IV Reverse Transcriptase & $\begin{array}{l}\text { Thermo Fisher } \\
\text { Scientific }\end{array}$ & $\begin{array}{l}\text { Catalogue number: } \\
18090050\end{array}$ \\
\hline FirstChoice $^{\mathrm{TM}}$ RLM-RACE Kit & Invitrogen & AM1700M \\
\hline GoTaq qPCR Mastermix & Promega & A6002 \\
\hline pGEM-T-Easy Vector System & Promega & A1360 \\
\hline Pierce BCA protein assay kit & $\begin{array}{l}\text { Thermo Fisher } \\
\text { Scientific }\end{array}$ & 23225 \\
\hline \multicolumn{3}{|l|}{ Experimental models: Cell lines } \\
\hline HeLa (Kyoto) & $\begin{array}{l}\text { S. Hapflmeier, IFIK, } \\
\text { University of Bern }\end{array}$ & \\
\hline \multicolumn{3}{|l|}{ Oligonucleotides } \\
\hline \multicolumn{3}{|l|}{ See Table S2 } \\
\hline \multicolumn{3}{|l|}{ Recombinant DNA } \\
\hline See Table S1 & & \\
\hline
\end{tabular}

\section{Methods}

\section{Bacterial strains and growth conditions}

E. coli $\mathrm{K} 12$ strain and its derivatives (Table S1) were grown at $37^{\circ} \mathrm{C}$ with shaking at $220 \mathrm{rpm}$ in LB (10 g tryptone, $10 \mathrm{~g} \mathrm{NaCl}$, and $5 \mathrm{~g}$ yeast extract per L). Exponential phase samples were taken at $\mathrm{OD}_{600}=0.4$ or at indicated time points after reaching this $\mathrm{OD}_{600}$. Stationary phase samples were taken 24,48 , or $72 \mathrm{~h}$ after initial inoculation. Induction with IPTG (Isopropyl $\beta$-d-1-thiogalactopyranoside) or tetracycline was done at $\mathrm{OD}_{600}=0.4$. All media were supplemented with kanamycin (25 $\mathrm{\mu g} / \mathrm{mL})$, ampicillin $(100 \mu \mathrm{g} / \mathrm{mL})$, streptomycin $(100 \mu \mathrm{g} / \mathrm{mL})$, IPTG $(1 \mathrm{mM})$, or tetracycline $(25 \mathrm{nM})$ where indicated. For the RNase E inactivation experiment, K12 and ${\text { rne } 3071^{\text {ts }}}$ (McDowall et al., 1993) strains were grown at $30^{\circ} \mathrm{C}$ to stationary phase and then the cultures were transferred to $43^{\circ} \mathrm{C}$. Salmonella strain SL1344 (Hoiseth and Stocker, 1981), M1525 (Suar et al., 2006), ATCC14028s (Fields et al., 1986), UK-1 (Dieye et al., 2009), and SB245 (Kaniga and Galan, unpublished) were 
grown at $37^{\circ} \mathrm{C}$ with shaking at $150 \mathrm{rpm}$ in LB supplemented with $0.3 \mathrm{M} \mathrm{NaCl}$. For northern blot analysis, Salmonella stationary phase samples were taken 48 and $72 \mathrm{~h}$ after initial inoculation.

\section{Construction of strains and plasmids}

fimR2S- $L$ and fimR2S-S were inserted, along with their downstream intergenic space, at the transcriptional +1 site under PlacO control in pBbE6k-RFP (Lee et al., 2011) by MEGAWHOP cloning (Miyazaki, 2011). For this, a pair of primers (See Table S2) were used to create a mega primer spanning the genomic fimR2S sequence by PCR using Phusion DNA Polymerase (NEB). The resulting PCR product was purified with Wizard $^{\circledR} \mathrm{SV}$ Gel and PCR Clean-Up (Promega) and used in excess to insert the sRNAs into the pBbE6k-RFP plasmid and replace the RFP sequence with PCR. The PCR reaction was digested with Dpnl (New England Biolabs) for $2 \mathrm{~h}$ at $37^{\circ} \mathrm{C}$ and transformed into $\mathrm{K} 12 \mathrm{E}$. coli competent cells. Plasmids were extracted from positive clones by Wizard ${ }^{\circledR}$ Plus SV Minipreps DNA Purification System (Promega) and sequenced with HL0199 primer (Microsynth). fimR2 mutants (CU, stem, loop, and A-U stem) were generated by onestep cloning PCR (Qi and Scholthof, 2008) using pBbE6k-fimR2 plasmid as a template (Raad et al., 2021). PCR reactions were Dpnl treated as previously mentioned, and subsequent transformation, plasmid extraction, and sequencing were carried out, as described for pBbE6k-fimRS-L and pBbE6k-fimRS-S. Using one-step cloning PCR, 18 base-pairs of fliJ sequence corresponding to codons 6-12 were inserted between the first and second codon of the RFP sequence in pBbA2ARFP. In a subsequent step, 12 additional base-pairs of the fliJ sequence corresponding to fliJ codons 2-5 were inserted upstream of the previous fliJ insert.

CsrA was amplified from K12 genomic DNA by PCR with primer pairs containing BamH1 and Ndel restriction sites and the histidine tag. The PCR product was then digested with both restriction enzymes as described and purified by size-exclusion electrophoresis. Ligation into BamH1/Ndel-cut backbone (pBbE6k-RFP with RFP excised) was done with T4 DNA Ligase (Promega). Subsequent subcloning was done as standard. Clones were confirmed by sequencing using HL0030 primer at Microsynth. 
Genomic deletion strains were created as described (Datsenko and Wanner, 2000). sRNA locus (fimR2, CsrB, and CsrC) and gene (CsrD)- specific primers (Table S2) were used to amplify a kanamycin cassette from pKD13 plasmid by PCR. Purified PCR product was electroporated into K12 E. coli strain containing the pKD46 plasmid and expressing lambda red recombinase through induction with $1 \mathrm{mM}$ Arabinose. Positive clones were recovered on LB agar plates supplemented with Kanamycin. Homologous recombination was confirmed by PCR as described in the PCR section. For the sRNA-deletion strains, the chromosomally-inserted Kanamycin cassette was removed by FLP recombination using pcp20 plasmid as previously described (Cherepanov and Wackernagel, 1995). Removal of the cassette was also confirmed by replica plating on LB agar plates with and without antibiotics, and by PCR.

\section{RNA extraction and northern blotting}

RNA extraction was performed with hot acidic phenol as described (Luidalepp et al., 2016). For northern blot analyses, 5-10 $\mu \mathrm{g}$ of total RNA were separated on denaturing polyacrylamide gels ( $8 \%$ Acrylamide M-Bis, 7 M Urea, $1 \times$ TBE), and gels were run for $2 \mathrm{~h}$ at $250 \mathrm{~V}$. RNA was transferred to a nylon membrane (Amersham Hybond-N+, GE Healthcare) using a semi-dry blotter (V20-SDB, Scie-Plas) and crosslinked to membranes using a microprocessor-controlled UV irradiation system (BLX-254, Vilber Lourmat). DNA oligonucleotides were end-labeled with $\left[\mathrm{Y}^{-}{ }^{32} \mathrm{P}\right]-\mathrm{ATP}$ (Hartmann Analytic) using PNK (Thermo Fisher Scientific) and used for hybridization as described (Gebetsberger et al., 2012).

For agarose gel northern blot, $20 \mu \mathrm{g}$ total RNA were resolved on a denaturing agarose gel (1.2\% agarose, $0.5 \%$ formaldehyde, $1 \times$ MOPS). RNA samples were transferred to a nylon membrane by capillary action in 20X SSC overnight at room temperature. After crosslinking RNA to membrane as mentioned, the membrane was incubated in 2xSSC buffer then in hybridization buffer at $65^{\circ} \mathrm{C}$ for $1 \mathrm{~h}$. The template for fimA probe was amplified by PCR from K12 genomic DNA then labelled with [ $\alpha$ $\left.{ }^{32} \mathrm{P}\right]-d C T P$ (Hartmann Analytic) with the Klenow fragment (Thermo Fisher Scientific) for $1 \mathrm{~h}$ at $37^{\circ} \mathrm{C}$. Hybridization was done overnight at $65^{\circ} \mathrm{C}$. Two washed were carried out on the following day for 30 min each in wash buffer I (2x SSC, $0.1 \%$ SDS) and II (0.2x SSC, $0.1 \%$ SDS). 


\section{Terminator exonuclease treatment}

Terminator exonuclease treatment was done according to manufacturer manual. One microgram of total RNA from stationary phase was mixed with 1 unit TEX (Lucigen) and 4 units of RNasin Plus RNase inhibitor (Promega) in buffer A and incubated at $30^{\circ} \mathrm{C}$ for $60 \mathrm{~min}$. Treated RNA was then phenol-chloroform extracted and precipitated in 2.5 volumes of $100 \%$ ethanol and $0.3 \mathrm{M}$ sodium acetate.

\section{In vitro transcription}

fimR2 and fimR2 precursor DNA templates were generated by PCR with primers containing the T7 promoter sequence (Table S2). After PCR cleanup with Wizard $^{\circledR}$ SV Gel and PCR Clean-Up (Promega), RNAs were transcribed by T7 polymerase as described (Erlacher et al., 2011). For crosslinking experiments, transcription was carried out using 4-thio-uridine (Jena Bioscience). All transcripts were purified by gel filtration with G-25 sephadex (Sigma). For 5'-end labelling for EMSA experiments and crosslinking experiments, in vitro transcribed fimR2 RNAs were dephosphorylated using CIP (New England Biolabs) at $37^{\circ} \mathrm{C}$ for $30 \mathrm{~min}$. RNA was purified by phenol-chloroform extraction and precipitation in ethanol. RNA was then further purified by size-exclusion electrophoresis and 5'-end labelled with PNK (Thermo Fisher Scientific).

\section{RNase E in vitro cleavage assay}

The purified amino-terminal domain of RNase $E$ was provided by B. F. Luisi (University of Cambridge). The following assay was carried out as described (Updegrove et al., 2018) in with some modifications. Briefly, in vitro transcribed fimR2 precursor was treated with $\mathrm{RppH}$ (New England Biolabs) in NEB Buffer 2.0 to remove a pyrophosphate from the triphosphorylated 5 '-end of the RNA. The reaction was carried out at $37^{\circ} \mathrm{C}$ for 30 min then purified with a phenol-chloroform extraction. For in vitro cleavage, RNA was heat-denatured at $95^{\circ} \mathrm{C}$ for 1 min then incubated at room temperature for 10 min. Afterwards, $300 \mathrm{mM}$ RNA was mixed with RNase $\mathrm{E}$ buffer (25 mM Tris $\mathrm{pH}=7.5,50 \mathrm{mM} \mathrm{NaCl}, 50 \mathrm{mM} \mathrm{KCl}, 10 \mathrm{mM} \mathrm{MgCl}_{2}, 1 \mathrm{mM}$ DTT), 4 units of RNasin Plus RNase inhibitor (Promega), and with or without $300 \mathrm{mM}$ CsrA- 
$\mathrm{His}_{10}$. The reactions were incubated at $30^{\circ} \mathrm{C}$ for 10 min then RNase $\mathrm{E}$ was added to a final concentration of $300 \mathrm{nM}(+), 600 \mathrm{nM}(++)$, or $900 \mathrm{nM}(+++)$. The reactions were then incubated at $30^{\circ} \mathrm{C}$ for an additional $30 \mathrm{~min}$ then phenol-chloroform extracted. RNA samples were precipitated at $-20^{\circ} \mathrm{C}$ overnight in 2.5 volumes $100 \%$ ethanol, 0.3 M sodium acetate, and glycoblue (Thermo Fisher Scientific). Precipitated RNA was resuspended in 2x RNA loading dye, resolved on denaturing polyacrylamide gels, and analyzed by northern blotting.

\section{Co-immunoprecipitation and protein purification}

CsrA-His $_{10}$ was overexpressed in exponential phase using IPTG. For coimmunoprecipitation experiments, $50 \mathrm{ml}$ cultures were harvested on the following day (24 h, stationary phase) from K12 and K12/pBbE6k-CsrA-His ${ }_{10}$. Bacterial pellets were lysed in lysis buffer $\left(50 \mathrm{mM} \mathrm{NaH}_{2} \mathrm{PO}_{4}, 300 \mathrm{mM} \mathrm{NaCl}, 10 \mathrm{mM}\right.$ imidazole at $\mathrm{pH}=$ 8.0), $1 \mathrm{mg} / \mathrm{mL}$ lysozyme, and $10 \mathrm{mM}$ VRC (New England Biolabs) for $30 \mathrm{~min}$ on ice. After sonication ( 6 rounds of $10 \mathrm{~s}$, with $10 \mathrm{~s}$ pausing on ice in between), lysates were passed through a narrow-gauge needle to disrupt genomic DNA. Cell lysates were cleared through centrifugation at $10,000 \mathrm{xg}$ for $30 \mathrm{~min}$. Cleared lysates were incubated with Ni-NTA resin (Qiagen) at $4^{\circ} \mathrm{C}$ on a roller shaker. Lysates were loaded on Poly-Prep chromatography columns (BioRad) and flow-through fractions were collected. Columns were washed twice in wash buffer $\left(50 \mathrm{mM} \mathrm{NaH} \mathrm{PO}_{4}, 300 \mathrm{mM}\right.$ $\mathrm{NaCl}, 20 \mathrm{mM}$ imidazole at $\mathrm{pH}=8.0)$. Beads were resuspended in elution buffer (50 $\mathrm{mM} \mathrm{NaH}{ }_{2} \mathrm{PO}_{4}, 300 \mathrm{mM} \mathrm{NaCl}, 250 \mathrm{mM}$ imidazole at $\mathrm{pH}=8.0$ ). For all the collected fractions (input, flow-through, beads), samples were taken for western blot analysis and leftover were used for RNA extraction using phenol-chloroform. Protein samples were analyzed by western blotting and RNA samples by northern blotting.

For CsrA-His ${ }_{10}$ purification, $100 \mathrm{ml}$ cultures were harvested $4 \mathrm{~h}$ following induction in exponential phase. Pellets were lysed in native lysis buffer, $1 \mathrm{mg} / \mathrm{ml}$ lysozyme and $10 \mathrm{mM}$ PMSF for 30 min on ice. After sonication and disruption of genomic DNA as described before, lysates were cleared by centrifugation. CsrA-His ${ }_{10}$ was then purified as described in the section on co-immunoprecipitation and using the Qiaexpressionist handbook. All fractions were analyzed by SDS-PAGE. Fractions containing CsrA-His ${ }_{10}$ were further confirmed by western blotting using mouse antiHis antibody (Protein Tech). Dialysis was performed overnight at $4^{\circ} \mathrm{C}$ in dialysis 
buffer (50 mM Tris- $\mathrm{HCl} \mathrm{pH}=8.0,150 \mathrm{mM} \mathrm{NaCl}, 10 \%$ glycerol, 1mM DTT) and using Spectrum Spectra/Por $3 \mathrm{RC}$ dialysis membrane tubing. Protein yield was quantified using Pierce BCA protein assay kit (Thermo Fisher Scientific).

\section{Western blotting}

For protein expression, purification and co-immunoprecipitation experiments, $5 \mu \mathrm{l}$ of cell suspension or fractions were mixed with equal volume $2 x$ Laemmli buffer and heated at $95^{\circ} \mathrm{C}$ for 5 min then loaded on 10-15\% SDS-PAGE gels. For RFP assays, $30 \mu \mathrm{g}$ total cleared cell lysates were mixed with $4 \mathrm{x}$ Laemmli buffer, boiled and loaded on SDS-gels. Protein samples were transferred to a nitrocellulose membrane (Sigma) using a semi-dry blotter (V20-SDB, Scie-Plas). Membranes were blocked in $1 \times$ PBSTM (1x PBS, $0.1 \%$ tween, $5 \%$ nonfat milk) for $1 \mathrm{~h}$ at room temperature on a shaker. Membranes were then incubated with the primary antibody prepared in $1 \mathrm{x}$ PBST in 1:5,000 dilution, overnight at $4^{\circ} \mathrm{C}$ on a rotary shaker. Membranes were washed three times in 1xPBST then incubated for $1 \mathrm{~h}$ at room temperature with Licor anti-mouse antibody $(1: 20,000)$. After three washes, membranes were dried then scanned with a Licor scanner and visualized using ImageQuant software.

\section{Crosslinking experiment}

In vitro transcribed fimR2 sRNA containing 4-thio-Us was denatured at $95^{\circ} \mathrm{C}$ for 2 min then allowed to refold at room temperature for $10 \mathrm{~min}$. The sRNA was then incubated with $30 \mu \mathrm{g}$ total cell lysates extracted and quantified as described for protein extraction. Incubation was done at $37^{\circ} \mathrm{C}$ for $30 \mathrm{~min}$. Samples destined for crosslinking were incubated on ice for 15 min under a UV lamp (365 nm). Control samples were incubated on ice without exposure to light. Proteinase $\mathrm{K}$ (Roth) treatment was done at $37^{\circ} \mathrm{C}$ for $15 \mathrm{~min}$. All samples were heated at $95^{\circ} \mathrm{C}$ for $5 \mathrm{~min}$ then loaded on an SDS-PAGE for analysis. The gel was stained in a Coomassie solution, destained in destaining buffer (50\% methanol, 10\% acetic acid), and then dried on Whatman paper and exposed to a phosphor imaging screen overnight. 


\section{RNA EMSA}

EMSA experiments were performed as described in Yakhnin et al. (2012). fimR2 5'end labelled RNA was heated at $85^{\circ} \mathrm{C}$ for 3 min then allowed to refold for $10 \mathrm{~min}$ at room temperature. RNA was then incubated with or without $\mathrm{CsrA}^{-\mathrm{His}_{10}}$ in binding buffer $\left(100 \mathrm{mM}\right.$ Tris- $\left.\mathrm{HCl} \mathrm{pH}=7.5,100 \mathrm{mM} \mathrm{MgCl}_{2}, 1 \mathrm{M} \mathrm{KCl}\right)$, and reaction mixture (7.5\% glycerol, $0.2 \mu \mathrm{g}$ yeast tRNA, 0.5\% bromophenol native dye, $20 \mathrm{mM}$ DTT, 0.04 U RNasin Plus RNase inhibitor). ICsrA-His ${ }_{10}$ was diluted in dilution buffer $(10 \mathrm{mM}$ Tris- $\mathrm{HCl} \mathrm{pH}=7.5,2 \mathrm{mM}$ DTT, $10 \%$ glycerol). Reactions were incubated at $37^{\circ} \mathrm{C}$ for 30 min then loaded on a $10 \%$ native gel (10\% acrylamide, $2.5 \%$ glycerol, $0.5 x$ TBE) and run for $1 \mathrm{~h}$ at $200 \mathrm{~V}$. The gel was then wrapped in plastic foil and exposed to a phosphor imaging screen at $-20^{\circ} \mathrm{C}$.

\section{RACE}

5'- and 3'-RACE experiments were conducted using the FirstChoice ${ }^{\mathrm{TM}}$ RLM-RACE Kit (Invitrogen) and as per manual description. Twenty micrograms of total RNA were separated on an $8 \%$ denaturing polyacrylamide gel and using Riboruler LR RNA ladder (Thermo Fisher Scientific), gel pieces corresponding to RNA bands in the range of 20-50 nucleotides were cut, crushed, and eluted overnight at $4^{\circ} \mathrm{C}$ in elution buffer (0.3 $\mathrm{M}$ sodium acetate $\mathrm{pH}=5.5,1 \mathrm{mM}$ EDTA). On the following day, the supernatant was precipitated in $100 \%$ ethanol. RNA was then poly-adenylated using E. coli Poly(A)-Polymerase (New England Biolabs) as suggested at $37^{\circ} \mathrm{C}$ for $30 \mathrm{~min}$. RNA was then purified from reaction components by a phenol-chloroform extraction. For 5'-RACE experiments, 5'-RACE adapter was annealed to template RNA using RNA Ligase (Thermo Fisher Scientific). cDNA synthesis was carried out using SuperScript IV reverse transcriptase (Thermo Fisher Scientific) with random hexamer primer (Thermo Fisher Scientific) with 10 -min cycles at $23^{\circ} \mathrm{C}, 55^{\circ} \mathrm{C}$, and $80^{\circ} \mathrm{C}$. For 3'-RACE experiments, 3'-RACE adapter was used as a primer for cDNA synthesis using Superscript IV with 10 -min cycles at $55^{\circ} \mathrm{C}$ and $80^{\circ} \mathrm{C}$. fimR2S-specific primers were then used in combination with 5'-RACE and 3'-RACE outer primers in a first amplification step, and 5'-RACE and 3'-RACE inner primers in a second amplification step. PCR reactions were carried out using a homemade Taq Polymerase. PCR products were purified using Wizard ${ }^{\circledR}$ SV Gel and PCR Clean-Up (Promega) and ligated into the pGEM-T-Easy vector (Promega) using supplied DNA 
Ligase. Ligated products were transformed into XL1-Blue competent cells. Plasmid extraction was done with Wizard ${ }^{\circledR}$ Plus SV Minipreps DNA Purification System (Promega). Inserts were sequenced using T7 universal primer from Microsynth.

\section{RT-qPCR}

RT-qPCR was conducted as described (Raad et al., 2021). One microgram of total RNA from all experimental conditions were treated with DNase I (Thermo Fisher Scientific) to digest DNA, according to the manufacturer's protocol. Samples were then reverse transcribed into cDNA with SuperScript ${ }^{\mathrm{TM}}$ IV One-Step RT-PCR System (Invitrogen) and random primer hexamers (Thermo Fischer Scientific). After reverse transcription, cDNA samples were treated with RNase $H$ (NEB) to hydrolyze leftover RNA. qPCR was done using GoTaq ${ }^{\circledR}$ qPCR Master Mix (Promega), 50-fold diluted cDNA, and a final concentration of $250 \mathrm{nM}$ to $1 \mathrm{M}$ of oligonucleotides. All primer pairs used for qPCR analysis were optimized using a standard curve. qPCR reactions were prepared by the CAS-1200 Corbett robot (Corbett Robotics) and analyzed using the Rotor Gene 6000, with suggested standard cycling conditions. recA was used as an internal control for the normalization of gene expression. All three biological replicates used for this analysis were run in duplicates. The $2^{-\triangle \Delta C T}$ method was used to calculate the fold-change relative to the control (Rao et al., 2013). The mean $\log _{2}$ fold-change and standard error of the mean were computed.

\section{PCR}

To confirm that the deletion strains acquired from the KEIO collection contain a kanamycin cassette instead of the ORF of the deleted locus, PCR amplification was done using oligonucleotides $\mathrm{K} 1$ and $\mathrm{K} 2$ combined with gene-specific primers (See Table S2) as suggested in Datsenko and Wanner (2000), and using home-made Taq Polymerase. For genomic DNA preparation, $1.5 \mathrm{~mL}$ of bacterial culture were lysed with $1.2 \mathrm{mg} / \mathrm{mL}$ Proteinase $\mathrm{K}$ (Roth) and 6\% SDS in TE buffer (10 mM Tris- $\mathrm{HCl}$ $\mathrm{pH}=8.0$ and $1 \mathrm{mM}$ EDTA), at $37^{\circ} \mathrm{C}$ for $1 \mathrm{~h}$. Genomic DNA was then extracted with 
basic phenol-chloroform extraction and precipitated in 2.5 volumes of $100 \%$ ethanol and $0.3 \mathrm{M}$ sodium acetate.

\section{Fluorescence assay}

For RFP experiments, $500 \mu \mathrm{l}$ of cultures, in 2 technical replicates, and 3 biological replicates were pipetted into 48-well plate (cellstar) following induction with IPTG and Tetracyclin. Fluorescence and $\mathrm{OD}_{600}$ were measured using Tecan plate reader with RFP excitation at $584 \mathrm{~nm}$ and emission at $607 \mathrm{~nm}$. Background fluorescence from bacterial strains with sRNA overexpression plasmids and target-RFP expression plasmids were subtracted from experimental data.

For sicA-GFP, analysis was done similarly and GFP fluorescence was measured using Tecan plate reader with GFP excitation at $488 \mathrm{~nm}$ and emission at $525 \mathrm{~nm}$. As fimR2S-S overexpression does not cause biofilm formation, fluorescence measurements were divided over $\mathrm{OD}_{600}$ of cultures (also measured using Tecan plate reader) to obtain absolute fluorescence. Background fluorescence from SB300 cells normalized over $\mathrm{OD}_{600}$ was subtracted from experimental samples.

\section{Biofilm assay}

Biofilms assays were conducted as described in Merritt et al. (2005) with minor modifications. Bacterial strains were diluted 1:100 from overnight cultures into fresh LB medium. $\mathrm{OD}_{600}=0.4,200 \mu$ of culture were inoculated in 96-well flat bottom microtiter plates (cellstar) for $2 \mathrm{~h}$ at $37^{\circ} \mathrm{C}$ (for exponential phase samples) and $22 \mathrm{~h}$ (for stationary phase samples). Planktonic bacteria were then removed by two washes with $\mathrm{H}_{2} \mathrm{O}$. Biofilms were then stained with $0.1 \%$ crystal violet in water for 15 min at room temperature. Wells were washed three times with $\mathrm{H}_{2} \mathrm{O}$ and crystal violet was solubilized with a solution of $80 \%$ Ethanol and $20 \%$ Acetone. OD $_{600}$ of solubilized crystal violet was measured using Vmax microplate reader (LabX Molecular Devices).

For micrographs, $500 \mu \mathrm{l}$ of cultures were inoculated in 12-well flat bottom plates (TPP) mounted with a coverslip and incubated as indicated for liquid culture-based biofilm assays. Coverslips were then washed with $\mathrm{H}_{2} \mathrm{O}$ and stained with $0.1 \%$ crystal 
violet as described. Dried coverslips were mounted on glass microscope slides and visualized using a Leica Microscope.

\section{Scanning Electron Microscopy}

For visualizing bacterial cells in suspension by scanning electron microscopy, $150 \mu \mathrm{l}$ of bacterial cells were taken from growing cultures $2 \mathrm{~h}$ after reaching $\mathrm{OD}_{600}=0.4$ (exponential phase) and $22 \mathrm{~h}$ post-inoculation (stationary phase). For inspecting biofilm potential, $1 \mathrm{~mL}$ of bacterial cells were inoculated in 24-well plate (TPP) mounted with $12 \mathrm{~mm}$ coverslips at $\mathrm{OD}_{600}=0.4$. Plates were incubated at $37^{\circ} \mathrm{C}$ for $2 \mathrm{~h}$ (exponential phase) or $22 \mathrm{~h}$ (stationary phase), under static conditions. Bacterial cell fixation was done as described in (Winzer et al., 2020). Briefly, cell pellets and coverslips were washed with $0.1 \mathrm{M}$ sodium cacodylate $(\mathrm{pH}=7.2)$ and fixed in $2 \%$ glutaraldehyde in sodium cacodylate buffer for $2 \mathrm{~h}$ at room temperature. Washes were done with $0.1 \mathrm{M}$ sodium cacodylate and samples were further fixed with $2 \%$ osmium tetroxide in sodium cacodylate for $2 \mathrm{~h}$ at room temperature. After washing with water, the samples were dehydrated in increasing concentrations of ethanol (30\%-100\%). Samples were then resuspended or immersed in hexamethyldisilazane and dried on metal SEM holders. Samples were sputter-coated with gold and visualized with a Zeiss Gemini 450 microscope operating at 5kV.

\section{HeLa infection assay}

HeLa invasion assays were carried out as described in (Pfister et al., 2020). Bacterial inocula for infection were cultured in LB medium with $0.3 \mathrm{M} \mathrm{NaCl}$ from overnight cultures at $37^{\circ} \mathrm{C}$ until $\mathrm{OD}_{550}=0.6$. Induction of SB300 strains containing pBbE6k-fimRS2-S was done with IPTG at $\mathrm{OD}_{550}=0.4$. Stationary phase samples were taken $24 \mathrm{~h}$ post-inoculation. HeLa (Kyoto) cells were seeded into 24-well plates (TPP) and grown in Dulbecco modified Eagle's medium (DMEM) supplemented with $10 \%$ fetal bovine serum (FBS) for $24 \mathrm{~h}$ at $37^{\circ} \mathrm{C}$. Before infection with SB300 cells and derivatives, adherent cells were washed then incubated in Hank's buffered salt (HBSS) for $10 \mathrm{~min}$. Infections were carried out using $3 \times 106 \mathrm{CFU}$ of bacteria per well, for $50 \mathrm{~min}$ at $37^{\circ} \mathrm{C}$. Extracellular bacteria were inactivated by the addition of DMEM containing $10 \%$ FBS and gentamicin $(400 \mu \mathrm{g} / \mathrm{mL})$ and subsequent incubation 
at $37^{\circ} \mathrm{C}$ for $30 \mathrm{~min}$. HeLa cells were then washed in PBS and lysed in $0.1 \%$ sodiumdeoxycholate in PBS to release intracellular bacteria. The initial bacterial inocula and intracellular loads were quantified on LB/agar plates containing Streptomycin and/or Kanamycin.

\section{CopraRNA Analysis}

The analysis was done using default parameters of CopraRNA and with a search for target interactions 300 nucleotides upstream and downstream mRNA start codon. As an input, the first 18 nucleotides of the fimR2 sequence were used (5'UUCAGGGACGUCAUUACG-3').

\section{MFold prediction}

fimR2 secondary structure was predicted using MFold algorithm (Zuker, 2003) with default values used for all parameters. The structure with the lowest predicted free energy is shown in this study.

\section{Statistical analysis}

Unpaired two-tailed t-test was used with Welsh's correction for all significance analysis and was conducted in Graphpad Prism. All analysis p-values are indicated in the figure legends.

\section{Supplemental Information title and legends}

Table S1: List of strains and plasmids.

\section{Table S2: List of oligonucleotides.}


bioRxiv preprint doi: https://doi.org/10.1101/2022.02.17.480891; this version posted February $17,2022$. The copyright holder for this preprint (which was not certified by peer review) is the author/funder, who has granted bioRxiv a license to display the preprint in perpetuity. It is made available under aCC-BY-NC-ND 4.0 International license.

\section{References}

ABRAHAM, J. M., FREITAG, C. S., CLEMENTS, J. R. \& EISENSTEIN, B. I. 1985. An invertible element of DNA controls phase variation of type 1 fimbriae of Escherichia coli. Proc Natl Acad Sci U S A, 82, 5724-7.

ALTIER, C., SUYEMOTO, M. \& LAWHON, S. D. 2000. Regulation of Salmonella enterica serovar typhimurium invasion genes by csrA. Infect Immun, 68, 6790-7.

BABA, T., ARA, T., HASEGAWA, M., TAKAI, Y., OKUMURA, Y., BABA, M., DATSENKO, K. A., TOMITA, M., WANNER, B. L. \& MORI, H. 2006. Construction of Escherichia coli K-12 inframe, single-gene knockout mutants: the Keio collection. Mol Syst Biol, 2, 2006.0008.

BABITZKE, P. \& KUSHNER, S. R. 1991. The Ams (altered mRNA stability) protein and ribonuclease $\mathrm{E}$ are encoded by the same structural gene of Escherichia coli. Proceedings of the National Academy of Sciences, 88, 1-5.

BAK, G., LEE, J., SUK, S., KIM, D., YOUNG LEE, J., KIM, K. S., CHOI, B. S. \& LEE, Y. 2015. Identification of novel sRNAs involved in biofilm formation, motility, and fimbriae formation in Escherichia coli. Sci Rep, 5, 15287.

BHATT, S., EDWARDS, A. N., NGUYEN, H. T., MERLIN, D., ROMEO, T. \& KALMAN, D. 2009. The RNA binding protein CsrA is a pleiotropic regulator of the locus of enterocyte effacement pathogenicity island of enteropathogenic Escherichia coli. Infect Immun, 77, 3552-68.

BOEHM, A., STEINER, S., ZAEHRINGER, F., CASANOVA, A., HAMBURGER, F., RITZ, D., KECK, W., ACKERMANN, M., SCHIRMER, T. \& JENAL, U. 2009. Second messenger signalling governs Escherichia coli biofilm induction upon ribosomal stress. Molecular Microbiology, 72, $1500-1516$.

CALLAGHAN, A. J., MARCAIDA, M. J., STEAD, J. A., MCDOWALL, K. J., SCOTT, W. G. \& LUISI, B. F. 2005. Structure of Escherichia coli RNase E catalytic domain and implications for RNA turnover. Nature, 437, 1187-1191.

CHAMBERS, J. R. \& SAUER, K. 2013. Small RNAs and their role in biofilm formation. Trends Microbiol, 21, 39-49.

CHAO, Y., LI, L., GIRODAT, D., FÖRSTNER, K. U., SAID, N., CORCORAN, C., ŚMIGA, M., PAPENFORT, K., REINHARDT, R., WIEDEN, H.-J., LUISI, B. F. \& VOGEL, J. 2017. In Vivo Cleavage Map Illuminates the Central Role of RNase $E$ in Coding and Non-coding RNA Pathways. Molecular Cell, 65, 39-51.

CHAO, Y. \& VOGEL, J. 2016. A 3' UTR-Derived Small RNA Provides the Regulatory Noncoding Arm of the Inner Membrane Stress Response. Molecular Cell, 61, 352-363.

CHEREPANOV, P. P. \& WACKERNAGEL, W. 1995. Gene disruption in Escherichia coli: TcR and $\mathrm{KmR}$ cassettes with the option of Flp-catalyzed excision of the antibiotic-resistance determinant. Gene, 158, 9-14.

DASGUPTA, S., FERNANDEZ, L., KAMEYAMA, L., INADA, T., NAKAMURA, Y., PAPPAS, A. \& COURT, D. L. 1998. Genetic uncoupling of the dsRNA-binding and RNA cleavage activities of the Escherichia coli endoribonuclease RNase III--the effect of dsRNA binding on gene expression. Mol Microbiol, 28, 629-40.

DATSENKO, K. A. \& WANNER, B. L. 2000. One-step inactivation of chromosomal genes in Escherichia coli K-12 using PCR products. Proceedings of the National Academy of Sciences, 97, 6640-6645.

DIEYE, Y., AMEISS, K., MELLATA, M. \& CURTISS, R. 2009. The Salmonella Pathogenicity Island (SPI) 1 contributes more than SPI2 to the colonization of the chicken by Salmonella enterica serovar Typhimurium. BMC Microbiology, 9, 3.

DOVE, S. L., SMITH, S. G. \& DORMAN, C. J. 1997. Control of Escherichia coli type 1 fimbrial gene expression in stationary phase: a negative role for RpoS. Mol Gen Genet, 254, $13-20$.

ERLACHER, M. D., CHIRKOVA, A., VOEGELE, P. \& POLACEK, N. 2011. Generation of chemically engineered ribosomes for atomic mutagenesis studies on protein biosynthesis. Nat Protoc, 6 , 580-92.

FIELDS, P. I., SWANSON, R. V., HAIDARIS, C. G. \& HEFFRON, F. 1986. Mutants of Salmonella typhimurium that cannot survive within the macrophage are avirulent. Proc Natl Acad Sci U S A, 83, 5189-93.

FIGUEROA-BOSSI, N., SCHWARTZ, A., GUILLEMARDET, B., D'HEYGÈRE, F., BOSSI, L. \& BOUDVILLAIN, M. 2014. RNA remodeling by bacterial global regulator CsrA promotes Rhodependent transcription termination. Genes Dev, 28, 1239-51.

FITZGERALD, D. M., BONOCORA, R. P. \& WADE, J. T. 2014. Comprehensive mapping of the Escherichia coli flagellar regulatory network. PLoS Genet, 10, e1004649. 
bioRxiv preprint doi: https://doi.org/10.1101/2022.02.17.480891; this version posted February 17, 2022. The copyright holder for this preprint (which was not certified by peer review) is the author/funder, who has granted bioRxiv a license to display the preprint in perpetuity. It is made available under aCC-BY-NC-ND 4.0 International license.

GALÁN, J. E. 2021. Salmonella Typhimurium and inflammation: a pathogen-centric affair. Nature Reviews Microbiology, 19, 716-725.

GEBETSBERGER, J., ZYWICKI, M., KÜNZI, A. \& POLACEK, N. 2012. tRNA-derived fragments target the ribosome and function as regulatory non-coding RNA in Haloferax volcanii. Archaea, 2012, 260909.

GHOSAL, A., UPADHYAYA, B. B., FRITZ, J. V., HEINTZ-BUSCHART, A., DESAI, M. S., YUSUF, D., HUANG, D., BAUMURATOV, A., WANG, K., GALAS, D. \& WILMES, P. 2015. The extracellular RNA complement of Escherichia coli. Microbiologyopen, 4, 252-266.

GRUBER, C. C., SPERANDIO, V. \& MCFALL-NGAI, M. J. 2014. Posttranscriptional Control of Microbe-Induced Rearrangement of Host Cell Actin. mBio, 5, e01025-13.

GUTIÉRREZ, P., LI, Y., OSBORNE, M. J., POMERANTSEVA, E., LIU, Q. \& GEHRING, K. 2005. Solution Structure of the Carbon Storage Regulator Protein CsrA from Escherichia coli. Journal of Bacteriology, 187, 3496-3501.

HANSMEIER, N., MISKIEWICZ, K., ELPERS, L., LISS, V., HENSEL, M. \& STERZENBACH, T. 2017. Functional expression of the entire adhesiome of Salmonella enterica serotype Typhimurium. Scientific Reports, 7, 10326.

HASE, K., KAWANO, K., NOCHI, T., PONTES, G. S., FUKUDA, S., EBISAWA, M., KADOKURA, K., TOBE, T., FUJIMURA, Y., KAWANO, S., YABASHI, A., WAGURI, S., NAKATO, G., KIMURA, S., MURAKAMI, T., IIMURA, M., HAMURA, K., FUKUOKA, S.-I., LOWE, A. W., ITOH, K., KIYONO, H. \& OHNO, H. 2009. Uptake through glycoprotein 2 of FimH+ bacteria by $\mathrm{M}$ cells initiates mucosal immune response. Nature, 462, 226-230.

HENDERSON, I. R., OWEN, P. \& NATARO, J. P. 1999. Molecular switches--the ON and OFF of bacterial phase variation. Mol Microbiol, 33, 919-32.

HENGGE-ARONIS, R. 2002. Signal transduction and regulatory mechanisms involved in control of the sigma(S) (RpoS) subunit of RNA polymerase. Microbiol Mol Biol Rev, 66, 373-95, table of contents.

HOISETH, S. K. \& STOCKER, B. A. 1981. Aromatic-dependent Salmonella typhimurium are nonvirulent and effective as live vaccines. Nature, 291, 238-9.

HÖR, J., MATERA, G., VOGEL, J., GOTTESMAN, S. \& STORZ, G. 2020. Trans-Acting Small RNAs and Their Effects on Gene Expression in Escherichia coli and Salmonella enterica. EcoSal Plus, 9.

HUNG, C.-C., EADE, C. R., BETTEKEN, M. I., PAVINSKI BITAR, P. D., HANDLEY, E. M., NUGENT, S. L., CHOWDHURY, R. \& ALTIER, C. 2019. Salmonella invasion is controlled through the secondary structure of the hilD transcript. PLOS Pathogens, 15, e1007700.

ITOH, Y., RICE, J. D., GOLLER, C., PANNURI, A., TAYLOR, J., MEISNER, J., BEVERIDGE, T. J., PRESTON, J. F., 3RD \& ROMEO, T. 2008. Roles of pgaABCD genes in synthesis, modification, and export of the Escherichia coli biofilm adhesin poly-beta-1,6-N-acetyl-Dglucosamine. J Bacteriol, 190, 3670-80.

JACKSON, D. W., SUZUKI, K., OAKFORD, L., SIMECKA, J. W., HART, M. E. \& ROMEO, T. 2002. Biofilm formation and dispersal under the influence of the global regulator CsrA of Escherichia coli. J Bacteriol, 184, 290-301.

JIANG, X. \& BELASCO, J. G. 2004. Catalytic activation of multimeric RNase E and RNase G by 5'monophosphorylated RNA. Proceedings of the National Academy of Sciences, 101, 92119216.

JØRGENSEN, M. G., THOMASON, M. K., HAVELUND, J., VALENTIN-HANSEN, P. \& STORZ, G. 2013. Dual function of the McaS small RNA in controlling biofilm formation. Genes Dev, 27, 1132-45.

JOSENHANS, C. \& SUERBAUM, S. 2002. The role of motility as a virulence factor in bacteria. International Journal of Medical Microbiology, 291, 605-614.

KAPER, J. B., NATARO, J. P. \& MOBLEY, H. L. T. 2004. Pathogenic Escherichia coli. Nature Reviews Microbiology, 2, 123-140.

KAWANO, M., REYNOLDS, A. A., MIRANDA-RIOS, J. \& STORZ, G. 2005. Detection of 5'- and 3'UTR-derived small RNAs and cis-encoded antisense RNAs in Escherichia coli. Nucleic Acids Research, 33, 1040-1050.

KLEMM, P. 1984. The fimA gene encoding the type-1 fimbrial subunit of Escherichia coli. Nucleotide sequence and primary structure of the protein. Eur J Biochem, 143, 395-9.

KOLENDA, R., UGORSKI, M. \& GRZYMAJLO, K. 2019. Everything You Always Wanted to Know About Salmonella Type 1 Fimbriae, but Were Afraid to Ask. Front Microbiol, 10, 1017.

LEE, T. S., KRUPA, R. A., ZHANG, F., HAJIMORAD, M., HOLTZ, W. J., PRASAD, N., LEE, S. K. \& KEASLING, J. D. 2011. BglBrick vectors and datasheets: A synthetic biology platform for gene expression. Journal of Biological Engineering, 5, 12. 
bioRxiv preprint doi: https://doi.org/10.1101/2022.02.17.480891; this version posted February 17, 2022. The copyright holder for this preprint (which was not certified by peer review) is the author/funder, who has granted bioRxiv a license to display the preprint in perpetuity. It is made available under aCC-BY-NC-ND 4.0 International license.

LIU, M. Y., GUI, G., WEI, B., PRESTON, J. F., III, OAKFORD, L., YÜKSEL, Ü., GIEDROC, D. P. \& ROMEO, T. 1997. The RNA Molecule CsrB Binds to the Global Regulatory Protein CsrA and Antagonizes Its Activity in Escherichia coli. Journal of Biological Chemistry, 272, 1750217510.

LOU, L., ZHANG, P., PIAO, R. \& WANG, Y. 2019. Salmonella Pathogenicity Island 1 (SPI-1) and Its Complex Regulatory Network. Frontiers in Cellular and Infection Microbiology, 9.

LUIDALEPP, H., BERGER, S., JOSS, O., TENSON, T. \& POLACEK, N. 2016. Ribosome Shut-Down by $16 \mathrm{~S}$ rRNA Fragmentation in Stationary-Phase Escherichia coli. J Mol Biol, 428, 2237-47.

MAI, J., RAO, C., WATT, J., SUN, X., LIN, C., ZHANG, L. \& LIU, J. 2019. Mycobacterium tuberculosis 6C sRNA binds multiple mRNA targets via C-rich loops independent of RNA chaperones. Nucleic Acids Research, 47, 4292-4307.

MARKOVA, J. A., ANGANOVA, E. V., TURSKAYA, A. L., BYBIN, V. A. \& SAVILOV, E. D. 2018. Regulation of Escherichia coli Biofilm Formation (Review). Applied Biochemistry and Microbiology, 54, 1-11.

MARTINEZ, J. J., MULVEY, M. A., SCHILLING, J. D., PINKNER, J. S. \& HULTGREN, S. J. 2000. Type 1 pilus-mediated bacterial invasion of bladder epithelial cells. Embo j, 19, 2803-12.

MARTÍNEZ, L. C., YAKHNIN, H., CAMACHO, M. I., GEORGELLIS, D., BABITZKE, P., PUENTE, J. L. \& BUSTAMANTE, V. H. 2011. Integration of a complex regulatory cascade involving the SirA/BarA and Csr global regulatory systems that controls expression of the Salmonella SPI-1 and SPI-2 virulence regulons through HilD. Mol Microbiol, 80, 1637-56.

MCCLAIN, M. S., BLOMFIELD, I. C. \& EISENSTEIN, B. I. 1991. Roles of fimB and fimE in sitespecific DNA inversion associated with phase variation of type 1 fimbriae in Escherichia coli. Journal of Bacteriology, 173, 5308-5314.

MCDOWALL, K. J., HERNANDEZ, R. G., LIN-CHAO, S. \& COHEN, S. N. 1993. The ams-1 and rne3071 temperature-sensitive mutations in the ams gene are in close proximity to each other and cause substitutions within a domain that resembles a product of the Escherichia coli mre locus. J Bacteriol, 175, 4245-9.

MELAMED, S., ADAMS, P. P., ZHANG, A., ZHANG, H. \& STORZ, G. 2020. RNA-RNA Interactomes of ProQ and Hfq Reveal Overlapping and Competing Roles. Molecular Cell, 77, 411-425.e7.

MERRITT, J. H., KADOURI, D. E. \& O'TOOLE, G. A. 2005. Growing and analyzing static biofilms. Curr Protoc Microbiol, Chapter 1, Unit 1B.1.

MINAMINO, T. \& NAMBA, K. 2004. Self-Assembly and Type III Protein Export of the Bacterial Flagellum. Microbial Physiology, 7, 5-17.

MITRA, A., PALANIYANDI, S., HERREN, C. D., ZHU, X. \& MUKHOPADHYAY, S. 2013. Pleiotropic roles of uvrY on biofilm formation, motility and virulence in uropathogenic Escherichia coli CFT073. PLoS One, 8, e55492.

MIYAZAKI, K. 2011. MEGAWHOP cloning: a method of creating random mutagenesis libraries via megaprimer PCR of whole plasmids. Methods Enzymol, 498, 399-406.

MOOR, J., AEBI, S., RICKLI, S., MOSTACCI, N., OVERESCH, G., OPPLIGER, A. \& HILTY, M. 2021. Dynamics of extended-spectrum cephalosporin-resistant Escherichia coli in pig farms: $A$ longitudinal study. International Journal of Antimicrobial Agents, 58, 106382.

NAVARRO LLORENS, J. M., TORMO, A. \& MARTÍNEZ-GARCÍA, E. 2010. Stationary phase in gramnegative bacteria. FEMS Microbiology Reviews, 34, 476-495.

NAZIRI, Z., KILEGOLAN, J. A., MOEZZI, M. S. \& DERAKHSHANDEH, A. 2021. Biofilm formation by uropathogenic Escherichia coli: a complicating factor for treatment and recurrence of urinary tract infections. Journal of Hospital Infection, 117, 9-16.

NITZAN, M., REHANI, R. \& MARGALIT, H. 2017. Integration of Bacterial Small RNAs in Regulatory Networks. Annu Rev Biophys, 46, 131-148.

PALCHEVSKIY, V. \& FINKEL, S. E. 2006. Escherichia coli competence gene homologs are essential for competitive fitness and the use of DNA as a nutrient. J Bacteriol, 188, 3902-10.

PFISTER, S. P., SCHÄREN, O. P., BELDI, L., PRINTZ, A., NOTTER, M. D., MUKHERJEE, M., LI, H., LIMENITAKIS, J. P., WERREN, J. P., TANDON, D., CUENCA, M., HAGEMANN, S., USTER, S. S., TERRAZOS, M. A., GOMEZ DE AGÜERO, M., SCHÜRCH, C. M., COELHO, F. M., CURTISS, R., SLACK, E., BALMER, M. L. \& HAPFELMEIER, S. 2020. Uncoupling of invasive bacterial mucosal immunogenicity from pathogenicity. Nature Communications, 11, 1978.

PICHON, C., DU MERLE, L., CALIOT, M. E., TRIEU-CUOT, P. \& LE BOUGUÉNEC, C. 2012. An in silico model for identification of small RNAs in whole bacterial genomes: characterization of antisense RNAs in pathogenic Escherichia coli and Streptococcus agalactiae strains. Nucleic Acids Res, 40, 2846-61. 
bioRxiv preprint doi: https://doi.org/10.1101/2022.02.17.480891; this version posted February 17, 2022. The copyright holder for this preprint (which was not certified by peer review) is the author/funder, who has granted bioRxiv a license to display the preprint in perpetuity. It is made available under aCC-BY-NC-ND 4.0 International license.

POTTS, A. H., VAKULSKAS, C. A., PANNURI, A., YAKHNIN, H., BABITZKE, P. \& ROMEO, T. 2017. Global role of the bacterial post-transcriptional regulator CsrA revealed by integrated transcriptomics. Nature Communications, 8, 1596.

POURCIAU, C., LAI, Y.-J., GORELIK, M., BABITZKE, P. \& ROMEO, T. 2020. Diverse Mechanisms and Circuitry for Global Regulation by the RNA-Binding Protein CsrA. Frontiers in Microbiology, 11.

PRATT, L. A. \& KOLTER, R. 1998. Genetic analysis of Escherichia coli biofilm formation: roles of flagella, motility, chemotaxis and type I pili. Molecular Microbiology, 30, 285-293.

QI, D. \& SCHOLTHOF, K. B. 2008. A one-step PCR-based method for rapid and efficient site-directed fragment deletion, insertion, and substitution mutagenesis. J Virol Methods, 149, 85-90.

RAAD, N., LUIDALEPP, H., FASNACHT, M. \& POLACEK, N. 2021. Transcriptome-Wide Analysis of Stationary Phase Small ncRNAs in E. coli. International Journal of Molecular Sciences, 22, 1703.

RAO, X., HUANG, X., ZHOU, Z. \& LIN, X. 2013. An improvement of the 2^(-delta delta CT) method for quantitative real-time polymerase chain reaction data analysis. Biostat Bioinforma Biomath, 3 , 71-85.

SANTIAGO-FRANGOS, A. \& WOODSON, S. A. 2018. Hfq chaperone brings speed dating to bacterial sRNA. 9, e1475.

SCHWAN, W. R. 2011. Regulation of fim genes in uropathogenic Escherichia coli. World J Clin Infect Dis, 1, 17-25.

SERRA, D. O., RICHTER, A. M., KLAUCK, G., MIKA, F., HENGGE, R. \& KOLTER, R. 2013. Microanatomy at Cellular Resolution and Spatial Order of Physiological Differentiation in a Bacterial Biofilm. mBio, 4, e00103-13.

SMIRNOV, A., WANG, C., DREWRY, L. L. \& VOGEL, J. 2017. Molecular mechanism of mRNA repression in trans by a ProQ-dependent small RNA. The EMBO Journal, 36, 1029-1045.

STERZENBACH, T., NGUYEN, K. T., NUCCIO, S. P., WINTER, M. G., VAKULSKAS, C. A., CLEGG, S., ROMEO, T. \& BÄUMLER, A. J. 2013. A novel CsrA titration mechanism regulates fimbrial gene expression in Salmonella typhimurium. Embo j, 32, 2872-83.

STURM, A., HEINEMANN, M., ARNOLDINI, M., BENECKE, A., ACKERMANN, M., BENZ, M., DORMANN, J. \& HARDT, W.-D. 2011. The Cost of Virulence: Retarded Growth of Salmonella Typhimurium Cells Expressing Type III Secretion System 1. PLOS Pathogens, 7, e1002143.

SUAR, M., JANTSCH, J., HAPFELMEIER, S., KREMER, M., STALLMACH, T., BARROW, P. A. \& HARDT, W.-D. 2006. Virulence of Broad- and Narrow-Host-Range Salmonella enterica Serovars in the Streptomycin-PretreatedMouse Model. Infection and Immunity, 74, 632-644.

SUZUKI, K., BABITZKE, P., KUSHNER, S. R. \& ROMEO, T. 2006. Identification of a novel regulatory protein (CsrD) that targets the global regulatory RNAs CsrB and CsrC for degradation by RNase E. Genes Dev, 20, 2605-17.

SY, B. M. \& TREE, J. J. 2021. Small RNA Regulation of Virulence in Pathogenic Escherichia coli. Frontiers in Cellular and Infection Microbiology, 10.

THOMASON, M. K., BISCHLER, T., EISENBART, S. K., FÖRSTNER, K. U., ZHANG, A., HERBIG, A., NIESELT, K., SHARMA, C. M. \& STORZ, G. 2015. Global transcriptional start site mapping using differential RNA sequencing reveals novel antisense RNAs in Escherichia coli. $J$ Bacteriol, 197, 18-28.

TIMMERMANS, J. \& MELDEREN, L. V. 2009. Conditional Essentiality of the csrA Gene in Escherichia coli. Journal of Bacteriology, 191, 1722-1724.

TUCKER, S. C. \& GALÁN, J. E. 2000. Complex function for SicA, a Salmonella enterica serovar typhimurium type III secretion-associated chaperone. J Bacteriol, 182, 2262-8.

UPDEGROVE, T. B., KOUSE, A. B., BANDYRA, K. J. \& STORZ, G. 2018. Stem-loops direct precise processing of 3' UTR-derived small RNA MicL. Nucleic Acids Research, 47, 1482-1492.

WANG, L., KEATCH, R., ZHAO, Q., WRIGHT, J. A., BRYANT, C. E., REDMANN, A. L. \& TERENTJEV, E. M. 2018. Influence of Type I Fimbriae and Fluid Shear Stress on Bacterial Behavior and Multicellular Architecture of Early Escherichia coli Biofilms at Single-Cell Resolution. 84.

WEILBACHER, T., SUZUKI, K., DUBEY, A. K., WANG, X., GUDAPATY, S., MOROZOV, I., BAKER, C. S., GEORGELLIS, D., BABITZKE, P. \& ROMEO, T. 2003. A novel sRNA component of the carbon storage regulatory system of Escherichia coli. Molecular Microbiology, 48, 657-670.

WESTERMANN, A. J., FÖRSTNER, K. U., AMMAN, F., BARQUIST, L., CHAO, Y., SCHULTE, L. N., MÜLLER, L., REINHARDT, R., STADLER, P. F. \& VOGEL, J. 2016. Dual RNA-seq unveils noncoding RNA functions in host-pathogen interactions. Nature, 529, 496-501. 
bioRxiv preprint doi: https://doi org/10.1101/2022 02 17.480891: this version posted February 17, 2022. The copyright holder for this

WILSON, J. W., SCHURR, M. J., LEBLANC, C. L., RAMAMURTHY, R., BUCHANAN, K. L. \& NICKERSON, C. A. 2002. Mechanisms of bacterial pathogenicity. Postgrad Med J, 78, 21624.

WINZER, P., MÜLLER, J., IMHOF, D., RITLER, D., ULDRY, A.-C., BRAGA-LAGACHE, S., HELLER, M., OJO, K. K., VAN VOORHIS, W. C., ORTEGA-MORA, L.-M. \& HEMPHILL, A. 2020. Neospora caninum: Differential Proteome of Multinucleated Complexes Induced by the Bumped Kinase Inhibitor BKI-1294. Microorganisms, 8, 801.

WRIGHT, K. J., SEED, P. C. \& HULTGREN, S. J. 2007. Development of intracellular bacterial communities of uropathogenic Escherichia coli depends on type 1 pili. Cell Microbiol, 9, 223041.

WRIGHT, P. R., GEORG, J., MANN, M., SORESCU, D. A., RICHTER, A. S., LOTT, S., KLEINKAUF, R., HESS, W. R. \& BACKOFEN, R. 2014. CopraRNA and IntaRNA: predicting small RNA targets, networks and interaction domains. Nucleic Acids Res, 42, W119-23.

YAKHNIN, A. V., BAKER, C. S., VAKULSKAS, C. A., YAKHNIN, H., BEREZIN, I., ROMEO, T. \& BABITZKE, P. 2013. CsrA activates flhDC expression by protecting flhDC mRNA from RNase E-mediated cleavage. Mol Microbiol, 87, 851-66.

YAKHNIN, A. V., YAKHNIN, H. \& BABITZKE, P. 2012. Gel mobility shift assays to detect protein-RNA interactions. Methods in molecular biology (Clifton, N.J.), 905, 201-211.

ZUKER, M. 2003. Mfold web server for nucleic acid folding and hybridization prediction. Nucleic Acids Research, 31, 3406-3415. 
A

\section{Control Buffer TEX}

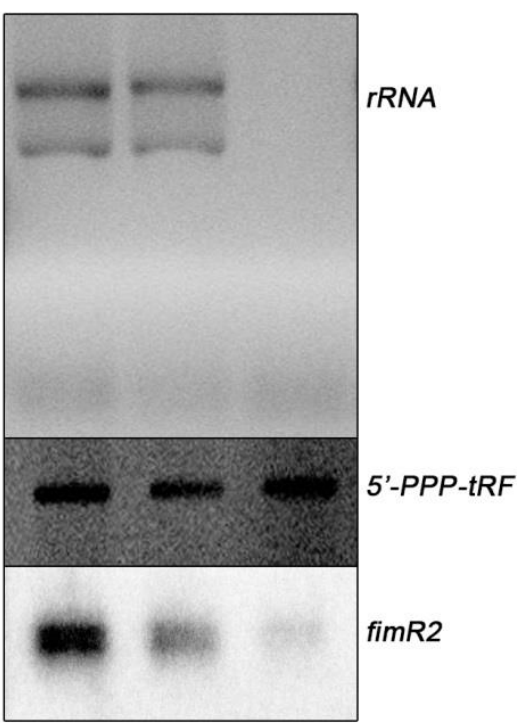

C

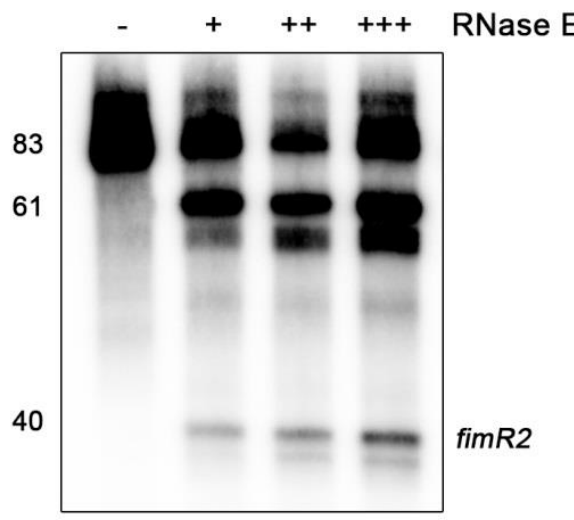

B

\begin{tabular}{|c|c|c|c|c|c|}
\hline \multicolumn{3}{|c|}{ WT } & \multicolumn{3}{|c|}{ rne3071-ts } \\
\hline 30 & & 43 & & & 43 \\
\hline$E$ & $S$ & $S$ & $E$ & S & $\mathrm{S}$ \\
\hline
\end{tabular}

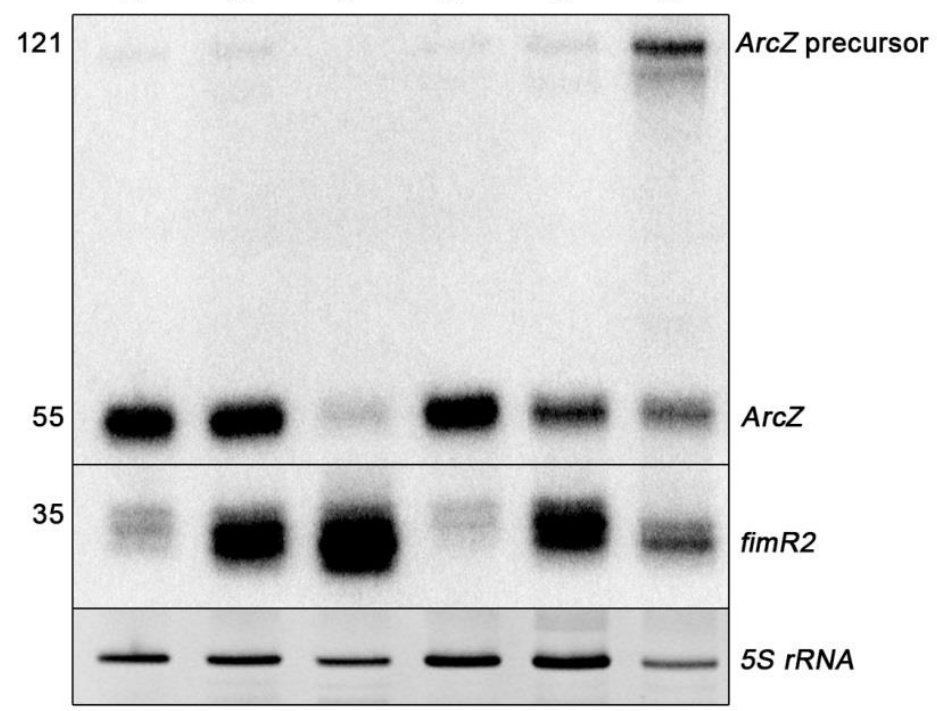

D

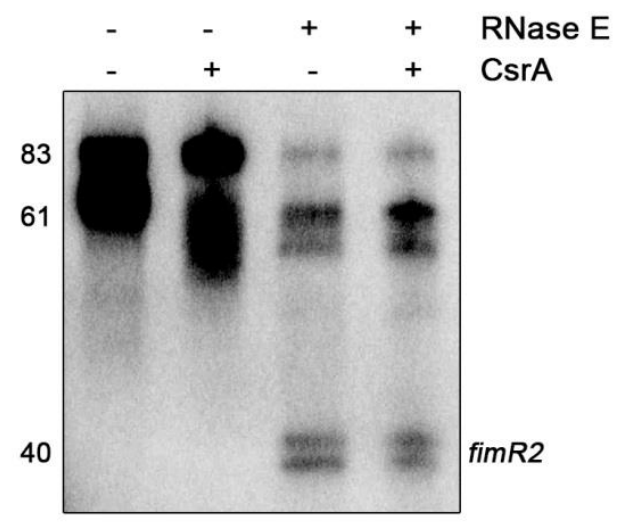

Figure 1: fimR2 is processed by RNase E. A. Ethidium bromide staining of ribosomal RNA and 5'-triphosphorylated tRNA fragment, and northern blot analysis of fimR2 upon TEX treatment. Total RNA samples were untreated (control), incubated with buffer, or with TEX. B. Northern blot analysis of fimR2 and ArcZ sRNAs expression in WT (wild-type) and $r n e 3071^{-t s}$ (RNase E temperature-sensitive) strains. $E$ and $S$ denote total RNA samples extracted from exponential phase and stationary phase, respectively, and from incubations at the indicated temperatures. Ethidium bromide staining of $5 S$ rRNA is shown as a loading control. C. Northern blot analysis of fimR2 following in vitro cleavage of a 5'- and 3'-extended precursor with $(+)$ and without (-) increasing amounts of RNase E. D. Northern blot analysis of fimR2 following in vitro cleavage of a 5'- and 3'-extended precursor with (+) or without (-) RNase $E$ and CsrA. In B-D the size of the different RNA molecules is indicated on the left. 
A
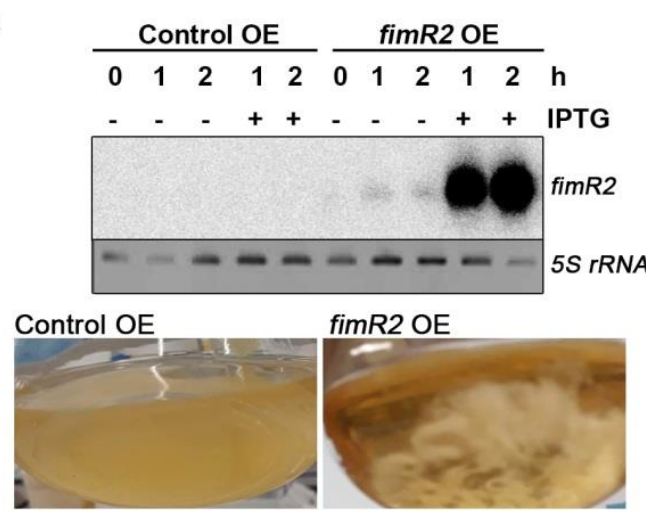

B

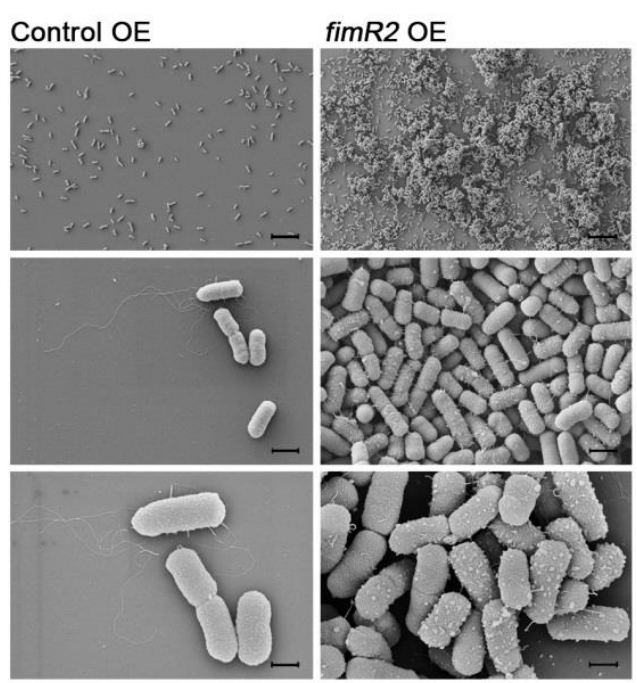

C

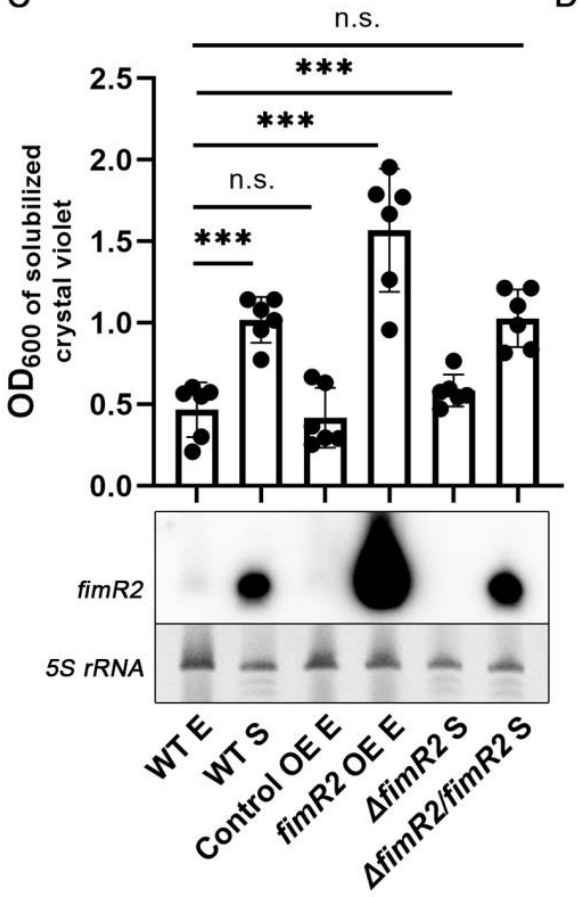

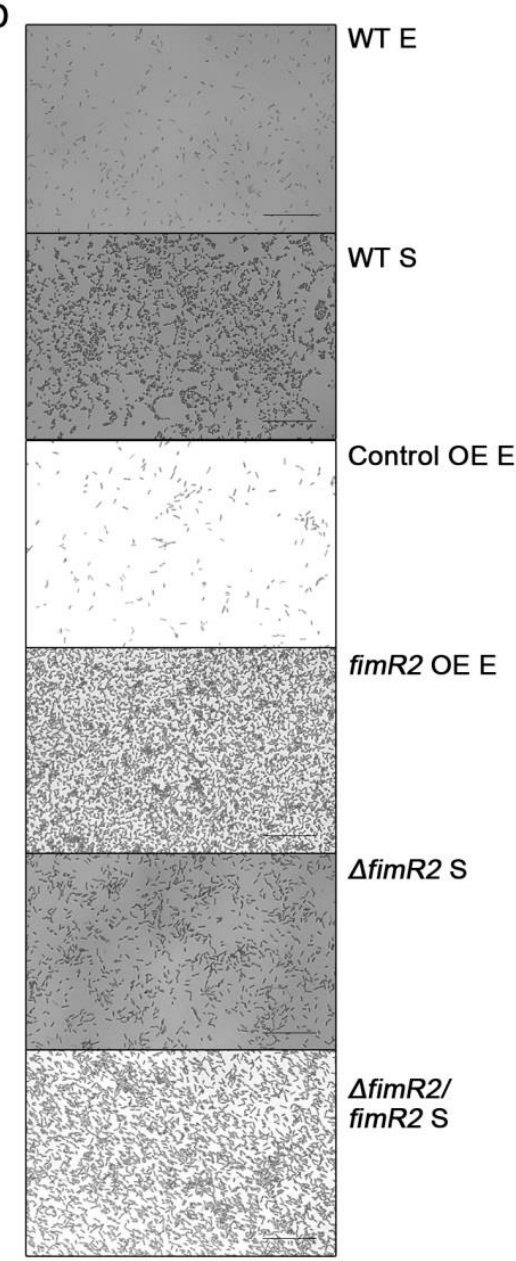

Figure 2: fimR2 regulates biofilm formation. A. Northern blot (top) of fimR2 expression in exponential phase following overexpression (OE) of the sRNA via IPTG induction. Pictures of resulting cultures are shown on the bottom. Control OE refers to the expression of a random short RNA sequence. Ethidium bromide staining of $5 S r R N A$ is shown as a loading control. B. Scanning electron micrographs of coverslip-formed biofilms of Control and fimR2 OE strains. Scale bars $=10 \mu \mathrm{m}$ (top), $1 \mu \mathrm{m}$ (middle), and $500 \mathrm{~nm}$ (bottom). C. Northern blot of fimR2 expression in WT (wild-type), Control OE, fimR2 OE (fimR2 overexpression), $\triangle$ fimR2 (fimR2 deletion), and $\Delta$ fimR2/fimR2 (fimR2 complementation) strains. Samples are shown from exponential $(E)$ and stationary $(S)$ phase. Ethidium bromide staining of 5S rRNA is shown as a loading control. D. Quantitative biofilm assay showing mean + SD $\mathrm{OD}_{600}$ of solubilized crystal violet-staining from six biological replicates of strains and conditions in C. Unpaired two-tailed t-test with Welch's correction was used to determine significance with n.s and ${ }^{* * *}$ showing not significant and significant results, respectively. The $p$-values are from bottom to top $0.6369,0.0003,0.0001,0.0002$, and 0.9202 , respectively. E. Micrographs of air-liquid phase biofilms stained with crystal violet, under conditions mentioned in C. Scale bar $=25 \mu \mathrm{m}$. 

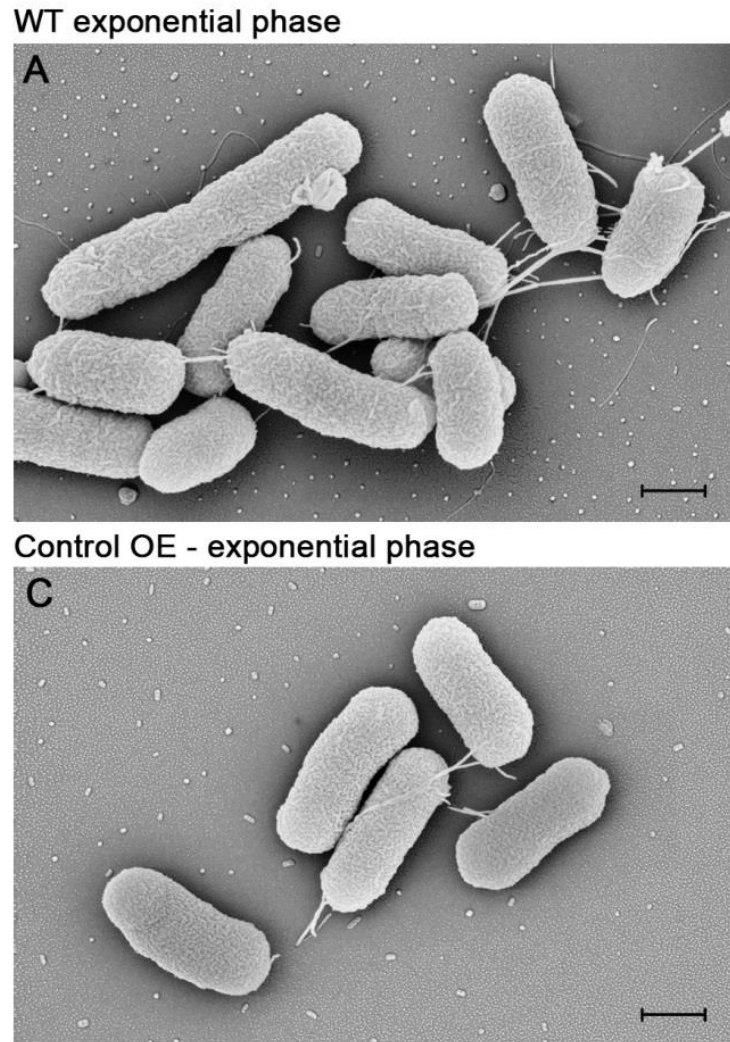

$\triangle$ fimR2 - stationary phase

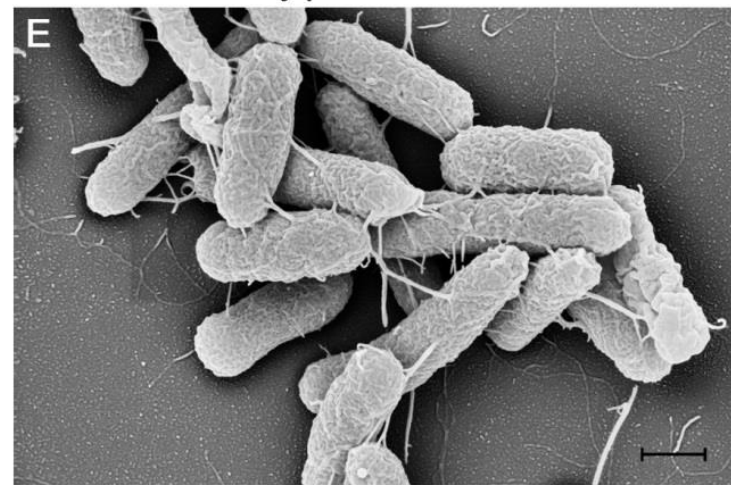

WT stationary phase

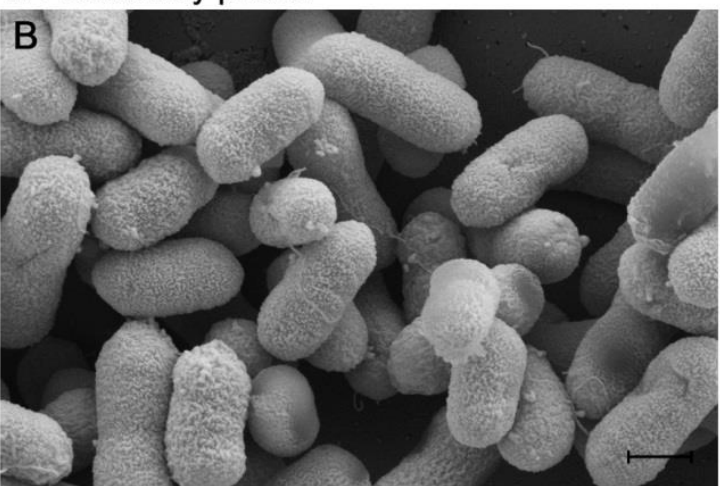

fimR2 OE - exponential phase

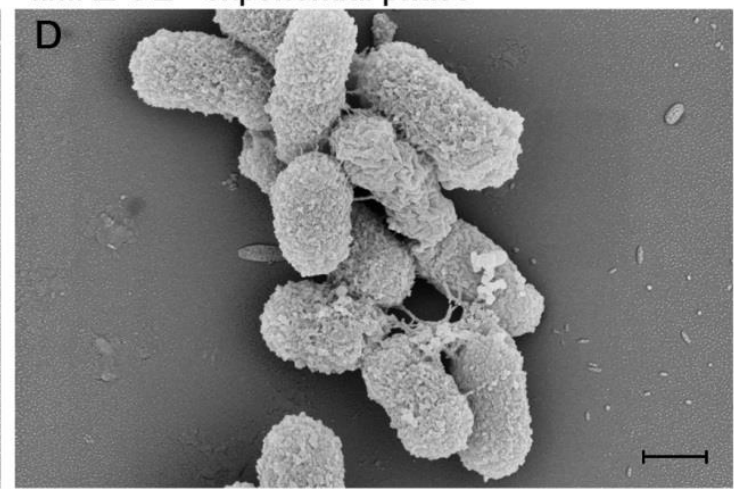

$\Delta$ fimR2/fimR2 - stationary phase

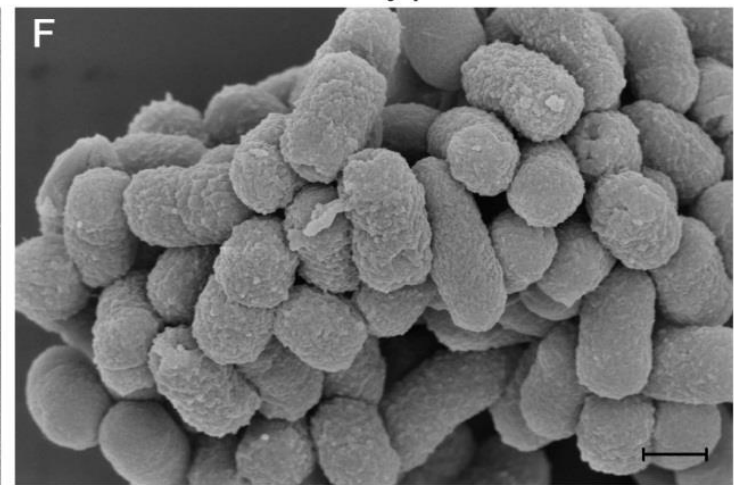

Figure 3: fimR2 alters bacterial outer membrane architecture. Scanning electron micrographs of E. coli $\mathrm{K} 12$ strains in A. WT exponential phase, B. WT stationary phase, C. Control OE (Control overexpression) in exponential phase, D. fimR2 OE (fimR2 overexpression) in exponential phase, E. $\Delta$ fimR2 in stationary phase, and F. $\Delta$ fimR2/fimR2 in stationary phase. Scale bar $=500 \mathrm{~nm}$. 

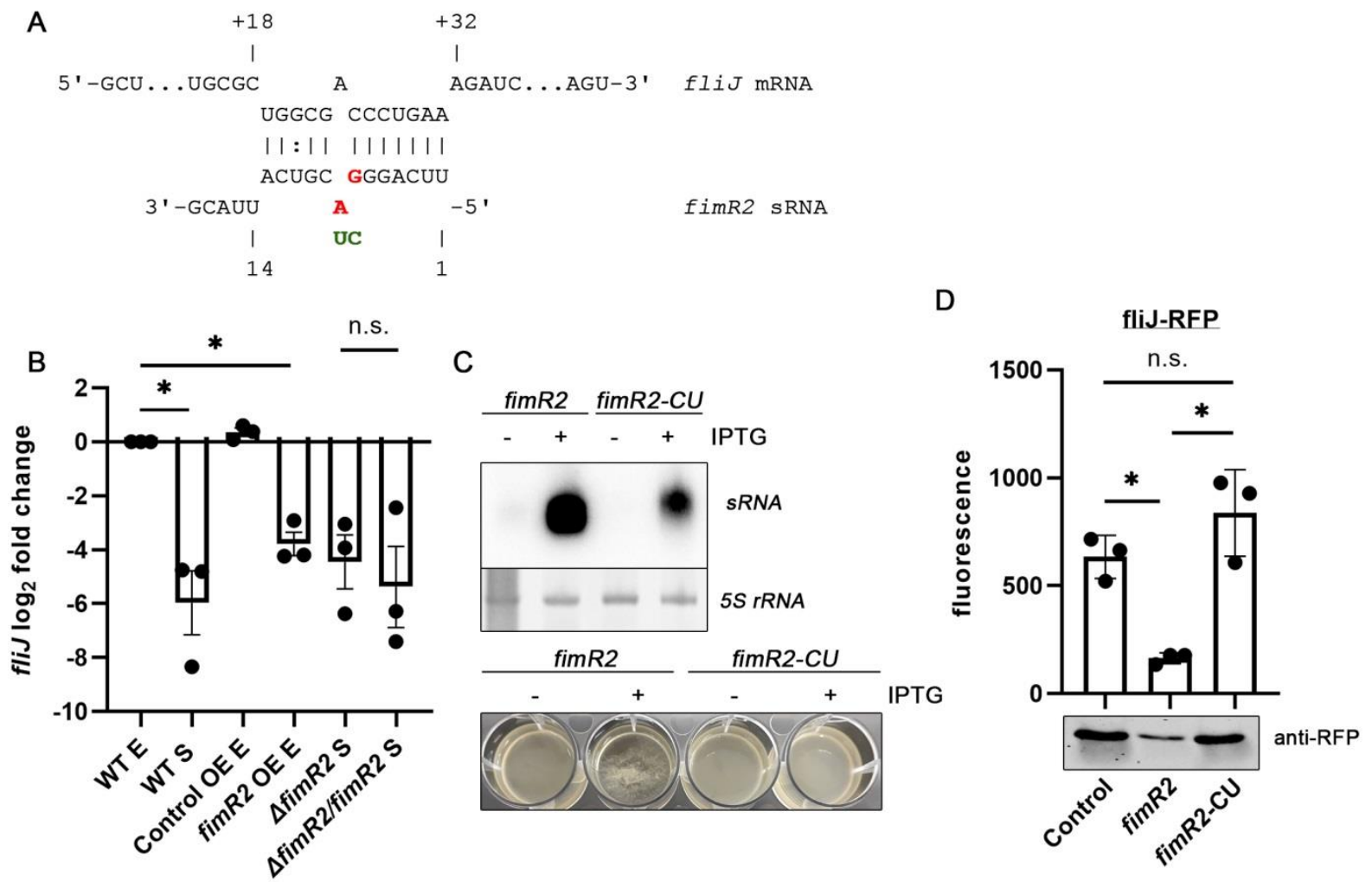

Figure 4: fimR2 regulates fliJ mRNA at the post-transcriptional level. A. fimR2fliJ predicted interaction. Mutated nucleotides are indicated in red, and their substitutions in green. B. RT-qPCR analysis of fliJ in WT, Control OE, OE, $\triangle$ fimR2, and $\triangle$ fimR2/fimR2 strains. Total RNA samples from $E$ (exponential phase) and $S$ (stationary phase) are shown. Mean $\log _{2}$ fold change + SEM are shown from 3 biological replicates. $\log _{2}$ fold change was based on comparison with WT E samples. Unpaired two-tailed t-test with Welch's correction was used to determine significance with n.s and * showing not significant and significant results, respectively. The $p$ values are $0.0373,0.0128$, and 0.6379 , respectively. C. Northern blot analysis of fimR2 and fimR2-CU (top) showing the expression of the sRNAs upon induction with IPTG. Ethidium bromide staining of $5 S$ rRNA is shown as a loading control. Pictures of bacterial cultures from the same conditions (bottom) showing the aggregation upon fimR2 overexpression. D. Mean + SD of fluorescence of the fliJ-RFP fusion protein following control, fimR2, or fimR2-CU overexpression (top) and RFP westernblot of the same samples (bottom). Three biological replicates were used for these experiments and background fluorescence from individual sRNA overexpression strains were subtracted from experimental values. Unpaired two-tailed t-test with Welch's correction was used to determine significance with n.s. and * showing not significant and significant results, respectively. The p-values are as follows: 0.0112 0.0268 and 0.2153 . 
A
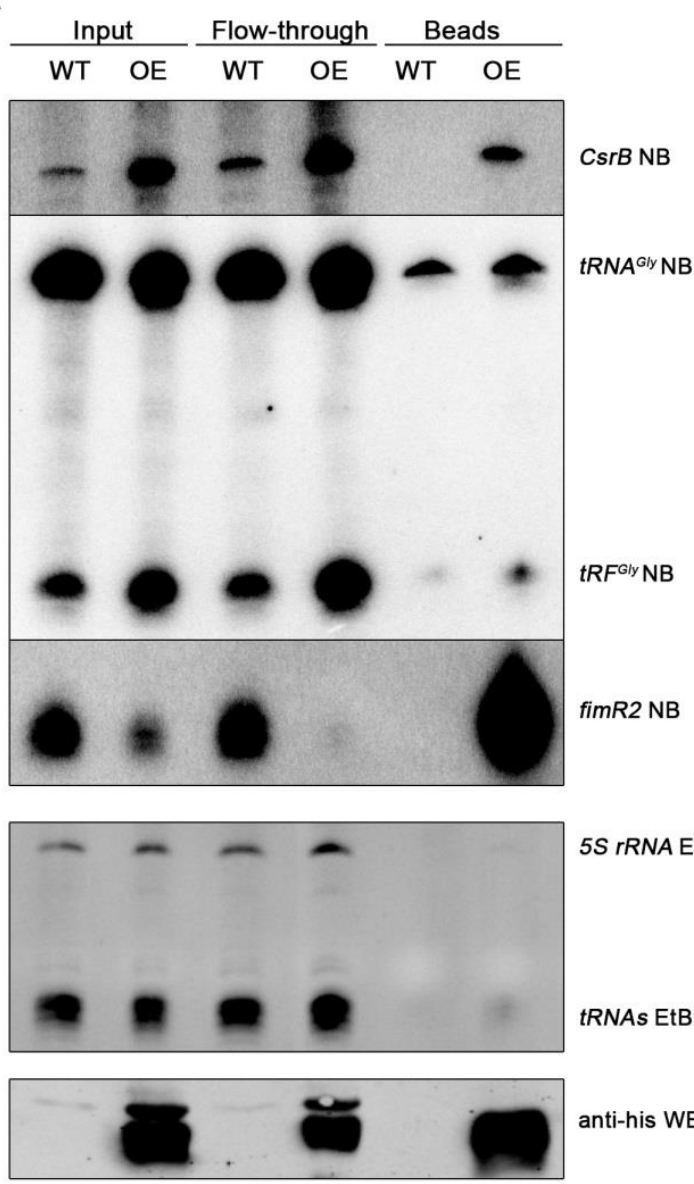

B

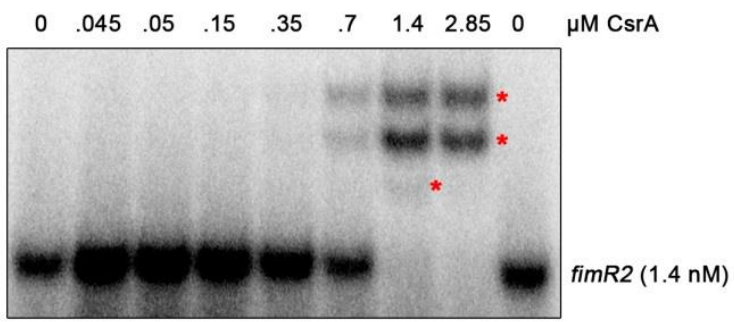

C

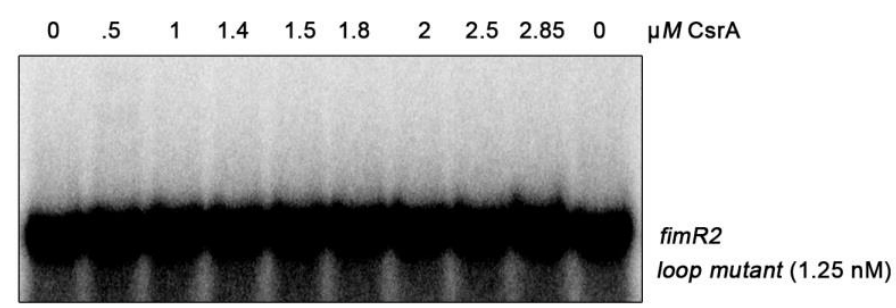

D

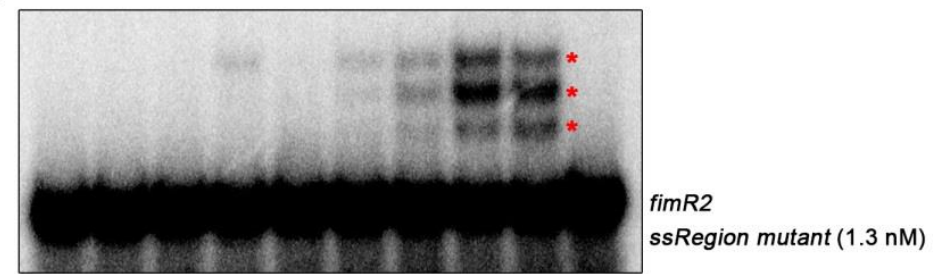

E

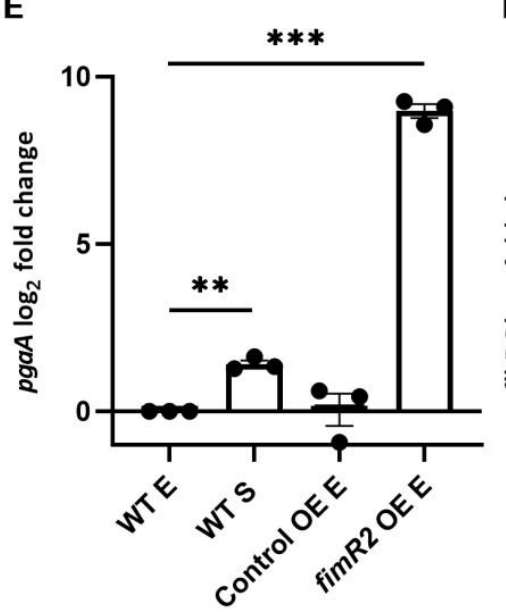

$\mathbf{F}$

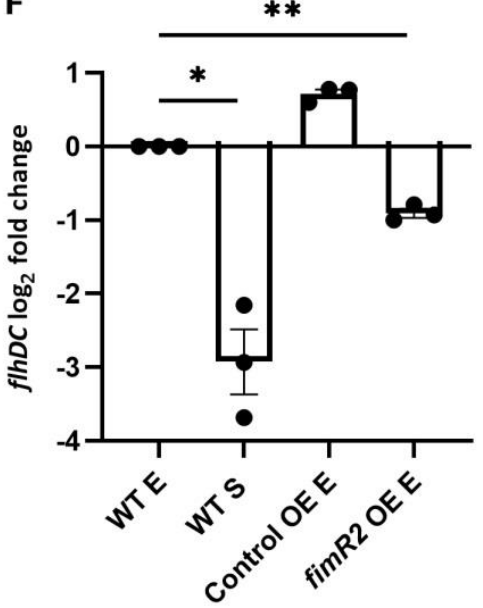

Figure 5: fimR2 sequesters CsrA from its targets. A. Northern blot of CsrB, 5'$t R F^{\text {Gly }}$, and fimR2 (top) from CsrA-his ${ }_{10}$ ColP fractions (top) and western blot of CsrA-his $_{10}$ from the same samples (bottom). Samples shown are taken from the stationary phase of growth of WT and OE (CsrA-his ${ }_{10}$ overexpression) strains. Ethidium bromide staining of $5 S$ rRNA and $t R N A s$ are shown as loading controls. B. EMSA of radioactively labelled fimR2 with increasing concentrations of purified CsrAhis ${ }_{10}$. C. EMSA of radioactively labelled fimR2 loop mutant with increasing concentrations of purified CsrA-his $_{10}$. D. EMSA of radioactively labelled fimR2 ssRegion mutant with increasing concentrations of purified CsrA-his ${ }_{10}$. Upshifts in B$\mathrm{D}$ are marked with red asterisks. E. RT-qPCR analysis of $p g a A$ and F. flhDC expression from WT, Control OE, and fimR2 OE. Samples from E (exponential phase) and $S$ (stationary phase) are shown. Mean $\log _{2}$ fold change + SEM are shown for both transcripts from 3 biological replicates. $\log _{2}$ fold change was based on comparison with exponential phase samples. Unpaired two-tailed t-test with Welch's correction was used to determine significance with * showing significant results. The p-values are E. 0.0058 and 0.005 , F. 0.0221 and 0.0046 . 
A

fimA TTATCATGAAATACGAATAATCCCGTCAGGGAACGCCAGGGAAGGGAG GAATAATCCCGTCAGGGAACGCAGGGAAGGGAG 34 bp

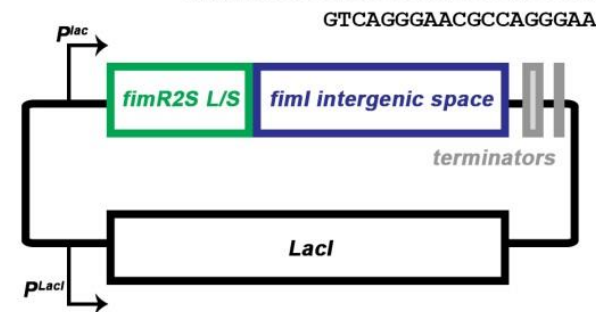

C

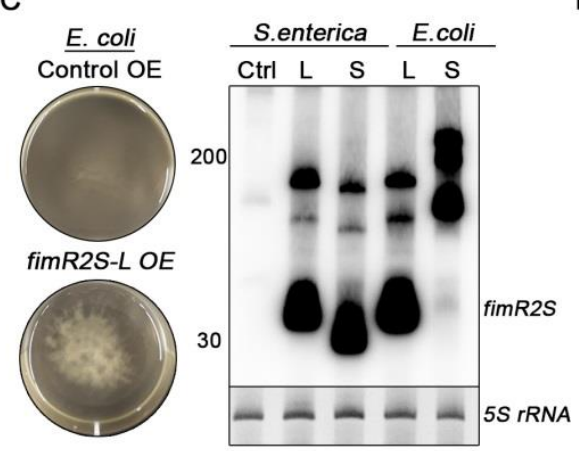

D

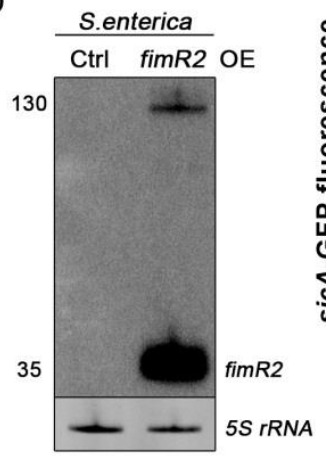

B

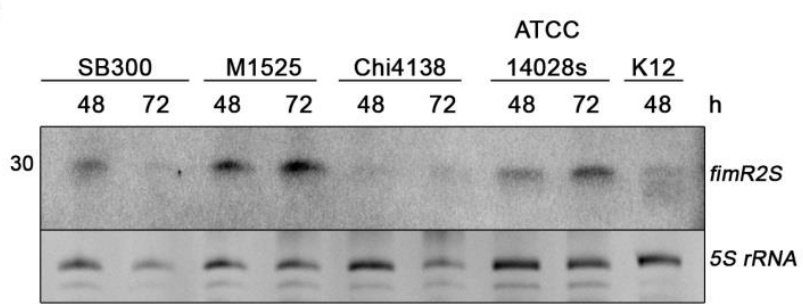

E

$\mathrm{F}$
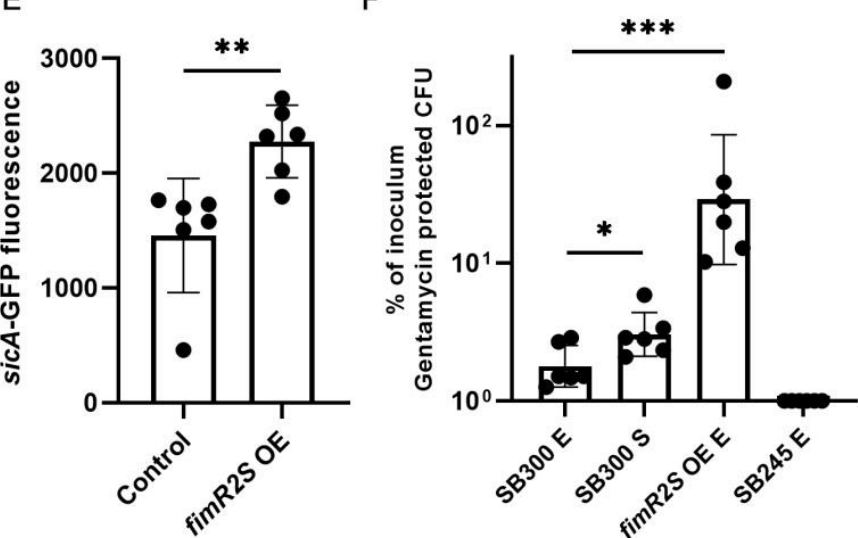

Figure 6: Salmonella fimR2S is involved in infection. A. 5'-RACE results mapped to $S$. enterica fimA sequence (top) and fimR2S expression plasmid (bottom). fimA stop codon is indicated in red. The predicted sequence for RNase $E$ cleavage based on analysis from Chao et al. (2017) is underlined. Sizes of recovered transcripts are indicated in bp (base pairs). B. Northern blot analysis of fimR2S in four Salmonella strains and the E. coli $\mathrm{K} 12$ strain. Total RNA samples from different time points of bacterial growth, 48 and $72 \mathrm{~h}$ (hours), are shown. Ethidium bromide staining of $5 S$ $r R N A$ is shown as a loading control. C. Pictures of Control and fimR2S-L OE in $E$. coli (left) and northern blot analysis of fimR2S expression in $S$. enterica and $E$. coli upon overexpression of fimR2S-L and fimR2S-S, the long and short fimR2S variants, respectively. Ctrl designate overexpression of the control. Ethidium bromide staining of $5 S$ rRNA is shown as a loading control. The size of the different RNA molecules is indicated on the left. D. Northern blot analysis of fimR2 expression in $S$. enterica under control and fimR2 OE conditions. Ethidium bromide staining of $5 S r R N A$ is shown as a loading control. E. Mean + SD of sicA-GFP fluorescence without (Control) or with fimR2S OE from six biological replicates. Unpaired two-tailed t-test with Welch's correction was used to determine significance with ** showing significant results and $p$-value of 0.0086 as compared to the control samples. $\mathbf{F}$. Mean + SD of percentage of inoculum protected from gentamicin treatment following infection of HeLa cells with an initial inoculum of SL1344 (SB300) from E (exponential phase) and $S$ (stationary phase), and fimR2S overexpression strains, from six replicate infections. SB245 strain is used as a negative control for invasion. Calculations were done following counting of colony forming units (CFU) of protected cells and initial inocula. Unpaired two-tailed t-test with Welch's correction was used to determine significance with * showing significant results. The $p$-values are, in order, 0.0280 and 0.0010 . 


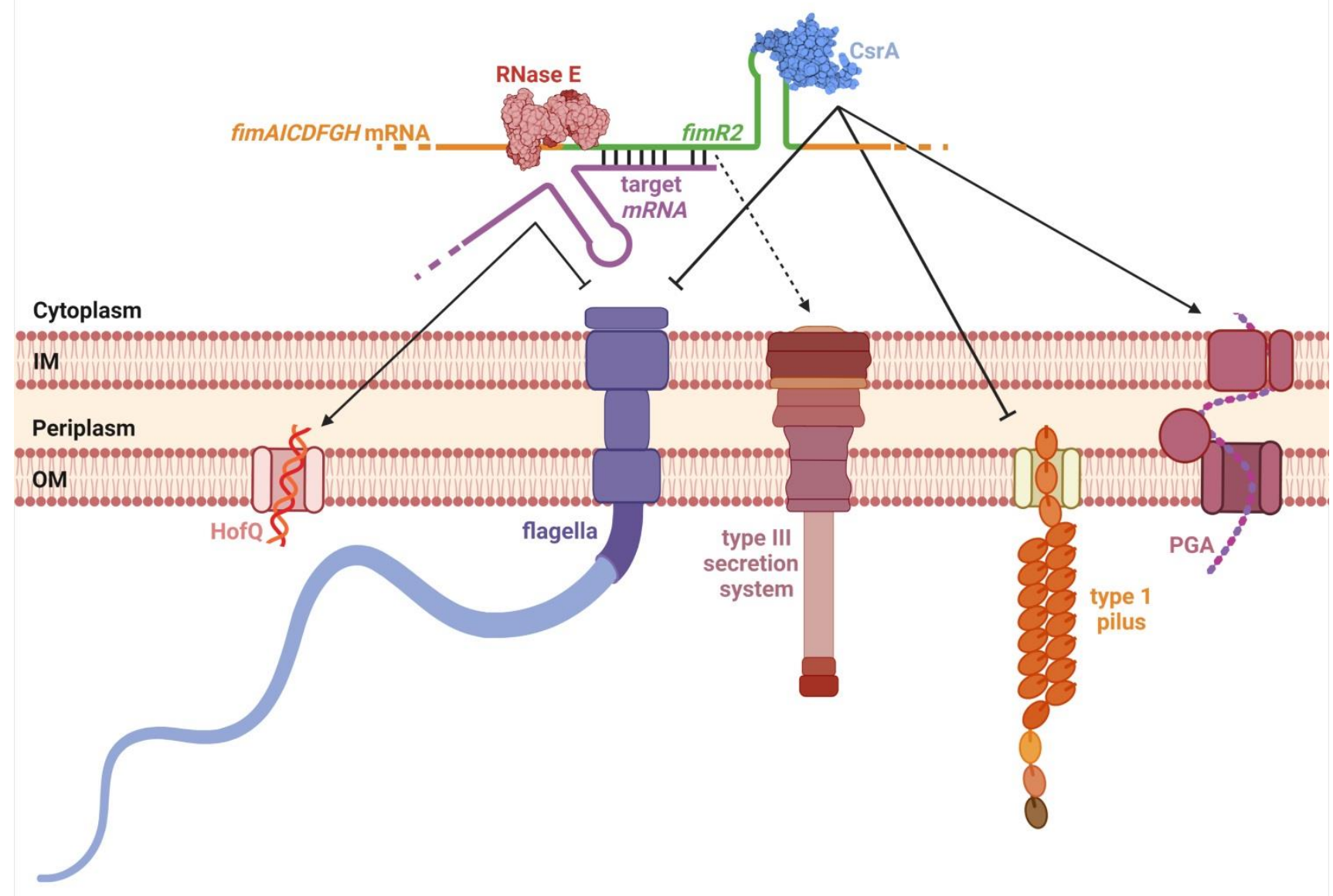

Figure 7: Model of fimR2 function. fimR2 sRNA is processed from the fimAICDFGH transcript in stationary phase by RNase E. The sRNA (green) interacts with the translational regulator CsrA and antagonizes its effects, upregulating PGA synthesis, and downregulating type 1 pilus and flagellar synthesis. fimR2 upregulates type III secretion likely through the sequestration of CsrA. In parallel, fimR2 regulates several transcripts through direct base-pairing, inhibiting flagellar synthesis and upregulating HofQ-mediated import of extracellular DNA for use in catabolic reactions. The crystal structure of RNase E catalytic domain (2C4R) and the NMR structure of CsrA (1Y00) were used (Callaghan et al., 2005, Gutiérrez et al., 2005). This figure was created with www.biorender.com. 